\title{
The Great American Biotic Interchange: Dispersals, Tectonics, Climate, Sea Level and Holding Pens
}

\author{
Michael O. Woodburne
}

Published online: 14 July 2010

(C) The Author(s) 2010. This article is published with open access at Springerlink.com

\begin{abstract}
The biotic and geologic dynamics of the Great American Biotic Interchange are reviewed and revised. Information on the Marine Isotope Stage chronology, sea level changes as well as Pliocene and Pleistocene vegetation changes in Central and northern South America add to a discussion of the role of climate in facilitating trans-isthmian exchanges. Trans-isthmian land mammal exchanges during the Pleistocene glacial intervals appear to have been promoted by the development of diverse non-tropical ecologies.
\end{abstract}

Keywords Great American Biotic Interchange $\cdot$ Central America $\cdot$ Biogeography $\cdot$ Pleistocene ice ages

\section{Introduction}

The Great American Biotic Interchange (Stehli and Webb 1985) refers to the exchange of land mammals that represents the strongest biogeographic link between North and South America ever achieved (Simpson 1950, 1953; Webb 1976, 1985; Marshall et al. 1982; Woodburne et al. 2006; Morgan 2008).

Woodburne et al. (2006) summarized aspects of Central American and Mexican faunas in this context. In addition to contributing to the mammalian range extensions of which the Great American Biotic Interchange (GABI) is comprised, these regions also served as a source of cladogenesis on one

Electronic supplementary material The online version of this article (doi:10.1007/s10914-010-9144-8) contains supplementary material, which is available to authorized users.

M. O. Woodburne $(\bowtie)$

Department of Geology, Museum of Northern Arizona,

Flagstaff, AZ 86001, USA

e-mail: mikew@npgcable.com hand, and a holding pen for certain taxa, on the other. Webb and Rancy (1996) evaluated centers of endemism for Neotropical mammal faunas of the late Cenozoic. Webb (1991) proposed that Great American Biotic Interchange (GABI) dispersals were aided by the development of Northern Hemisphere glaciations that promoted the development of savanna-like ecologies in Central America, in contrast to their generally tropical character, and thereby permitted savanna-adapted mammals to cross between North and South America. The formulation of a succession of astronomically-calibrated oxygen isotope curves, summarized in Lisecki and Raymo (2005) has provided a detailed chronology of oceanic temperature changes during the past $5 \mathrm{Ma}$. Sosdian and Rosenthal (2009) offered a detailed scale of sea level changes during the past $3.2 \mathrm{Ma}$, and Bartoli et al. (2005) presented a valuable analysis of the final closure of the Isthmus of Panama. Papers by Graham and Dilcher (1998) and others, including Piperno (2006), Andreissen et al. (1993), and Bush et al. (2004), aid in the discussion of Pliocene and Pleistocene vegetation and climatic patterns in Central and northern South America.

The purpose of the present paper is to integrate the above and pursue the roles played by tectonics, climate, sea level, and holding pens in facilitating or otherwise affecting the exchange of land vertebrates across the Panamanian isthmus during GABI. Figure 1 shows the districts and faunal sites discussed in the text.

\section{Abbreviations and definitions \\ CAS Central American Seaway; Bartoli et al. (2005). \\ Central America The region encompassed between the southern border of Panama and the Isthmus of Tehuantepec, Mexico (Fig. 1).}


Endemic

GABI

GP

GPTS

holding pen

IRD

ky

Local Fauna

$\mathrm{Ma}$ a taxon that either phyletically originates in, or is introduced to, but in any case subsequently remains restricted to, the area indicated. Great American Biotic Interchange. GABI began about 2.6 Ma (see text). Glacial pulse corresponding to a MIS in Fig. 7 that represents a strong departure from the general pattern during a time of stable or lowering of mean sea level as indicated by the heavy black line thereupon. This is noted as GP in Fig. 4 opposite MIS stages numbered in italic boldface in both Figs. 4 and 7 .

Geomagnetic Polarity Time Scale (after Lourens et al. 2004).

this refers to situations in which a taxon occurs earlier in a given location, only to be found later on in an adjacent area. As discussed below and by Flynn et al. (2005), a number of taxa have an earlier record in deposits of the Guanajuato region of central Mexico (G; Fig. 1) relative to their first occurrence in the United States. In that case, the Mexican record is considered as having been a holding pen with respect to the later occurrence. All references in the text to Flynn et al. (2005) refer to this record in Guanajuato.

Ice-rafted debris, in the context of indicating episodes of Northern Hemisphere Glaciation (NHG) (Bartoli et al. 2005) and other significant glacial events (Lawrence et al. 2009).

Kiloyear, a segment of geologic time 1,000 years in duration or the age of an event (e.g., 200,000 years ago) without reference to a point or a set of points on the radioisotopic time scale.

This (also abbreviated L.F.) is an aggregate of fossil vertebrates that have a limited distribution in time and space, derived from a number of closely grouped localities in a limited geographic area. See Tedford (1970). A local fauna could be based on taxa from as single locality.

Megannum. One million years in the radioisotopic time scale (e.g., $10 \mathrm{Ma}$ refers to the 10 million year point on that time scale).
MIS

m.y.

NALMA

Neogene Period

NHG

North America

PCO

SALMA

South America

\section{Tectonic background}

The traditional viewpoint has been that GABI signaled the development of an overland corridor across the Panamanian region, and that this transpired about 3.0 Ma (e.g., Marshall et al. 1979, 1982 and references cited therein). It also was recognized that there had been a limited exchange of taxa in both directions prior to this time, and presumably prior to the development of a well-defined 'land bridge', with the precursors being designated variably as 'heralds' (Webb 1976, 1985, 2006) or New Island Hoppers, with the latter appellation indicating the method of dispersal (Simpson 1950).

The geologic and tectonic reconstructions of Coates et al. (2004) indicate that the Panamanian region contained a series of islands as early as $6 \mathrm{Ma}$ (Fig. 2), with the formerly through-going Central American Seaway (CAS) being largely interrupted by an evolving volcanic arc as early as about $12 \mathrm{Ma}$, as the southwestern margin of the Caribbean Plate collided with the South American continent. 
Fig. 1 Map of Florida, Mexico, and Central America showing fossil localities and other areas discussed in the text.

$\mathrm{EG}=\mathrm{El}$ Golfo, Mexico;

$\mathrm{ES}=\mathrm{El}$ Salvador; $\mathrm{G}=$ Guanajuato, Mexico; $\mathrm{Gu}=$ Guatemala; $\mathrm{H}=$ Honduras; $\mathrm{IT}=\mathrm{Isthmus}$ of Tehuantepec; L = Leisey Bone Bed, Florida; $\mathrm{Ni}=$ Nicaragua; $\mathrm{P}=$ Panama; $\mathrm{TMVB}=$ Transmex ican Volcanic Belt.

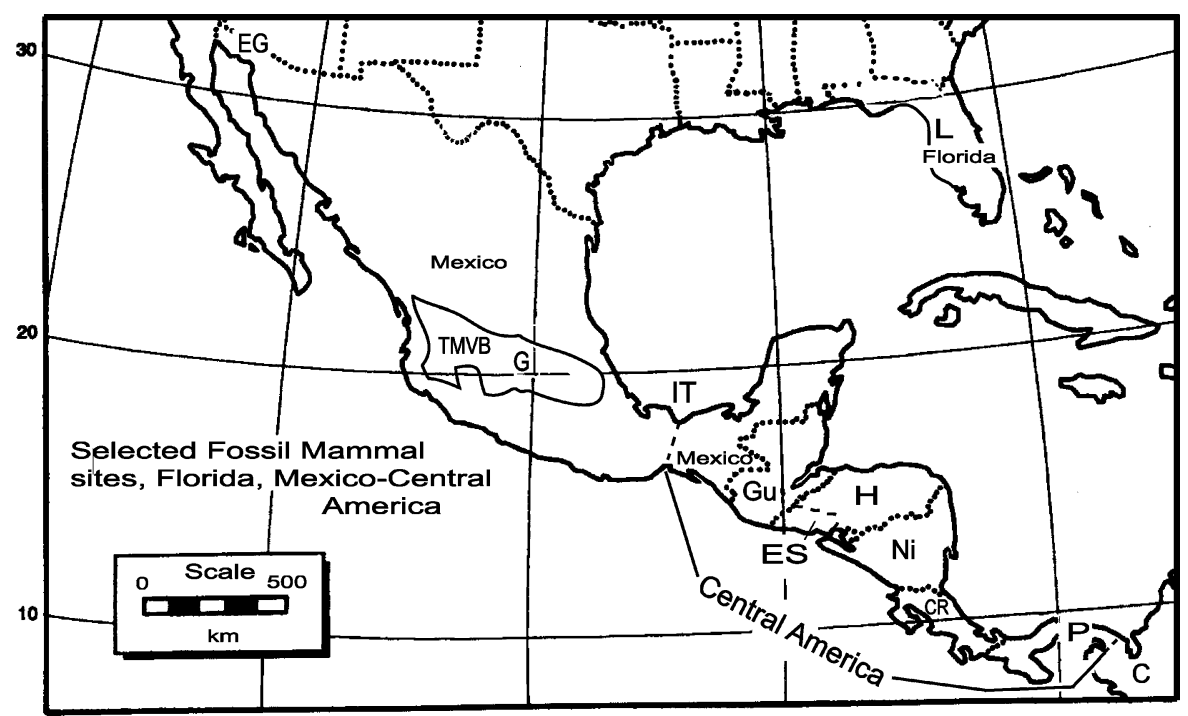

Tectonic highlights include a widespread unconformity at about 8.6-7.1 Ma that reflects complete docking and widespread uplift of the Central American Isthmus (including Panama). This apparently fostered the 7.3 Ma entry of the Procyonidae to South America (Fig. 3).

From Costa Rica to Colombia (Fig. 2), marine deposits reflect shallow marine (neritic) conditions adjacent to emergent lands between about 7.1-4.0 Ma (and 4.8 Ma in Colombia; 4.0 Ma in Costa Rica) subsequent to which the region was further strongly uplifted, including the final emergence of the Panamanian district. In this context (including a brief increase of marine flooding about $6 \mathrm{Ma}$; Coates et al. 2004), overall conditions reflected increased shallowing of the CAS until about $2.8 \mathrm{Ma}$ (Bartoli et al.
2005), after which time the isthmian region apparently was dry land.

From the evidence in Fig. 3 and the following discussion of the dispersal pattern (Fig. 4) it appears that land mammals began to extend their ranges across Central America soon after the initial tectonic closure from about $12 \mathrm{Ma}$. Whereas the first sloths arrived in North America at about $9 \mathrm{Ma}$, that is only a minimum age regarding their actual crossing of the isthmian region, and whether they were present in Central America prior to their occurrence in continental North America remains to be determined. In fact, the degree to which Central America acted as a holding pen for any trans-isthmian dispersal remains an open question, considered further below.

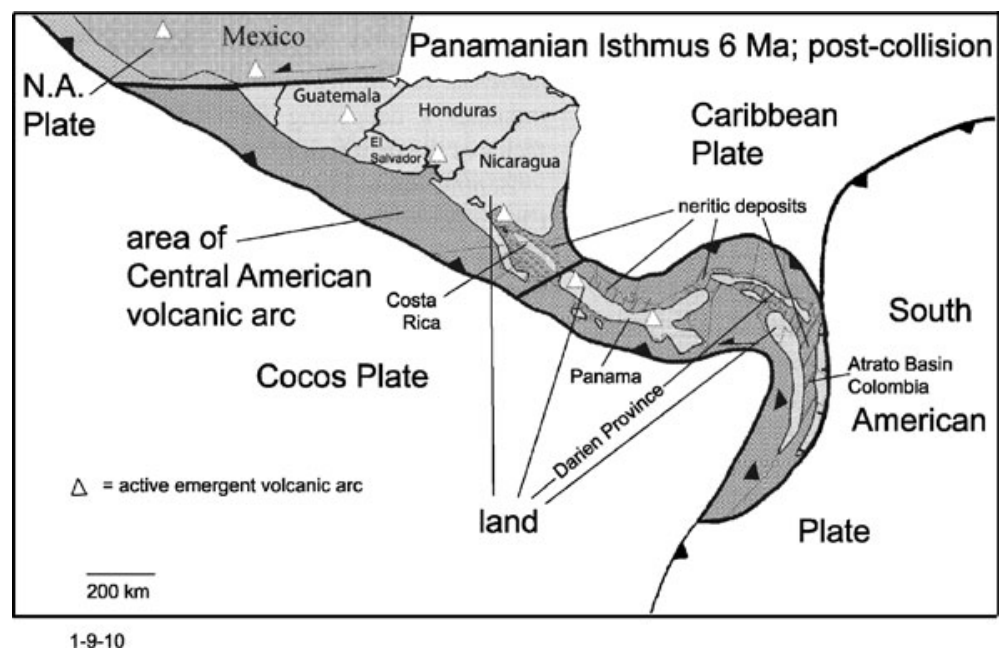

Fig. 2 Reconstruction of the geologic setting of the Central American volcanic arc region at $6 \mathrm{Ma}$, after Coates et al. (2004: fig. 8c). The Central American volcanic arc is still active (open triangles) subsequent to a major plate collision between 8.6-7.1 Ma. The presence of numerous islands as well as emergent land in Mexico,
Guatemala, Honduras, Nicaragua, and Colombia sets the stage for the Great American Biotic Interchange well prior to the final closure of the Central American Seaway, perhaps as late as 2.8 Ma. Neritic conditions dominated near island segments prior to a brief bathyal incursion. 


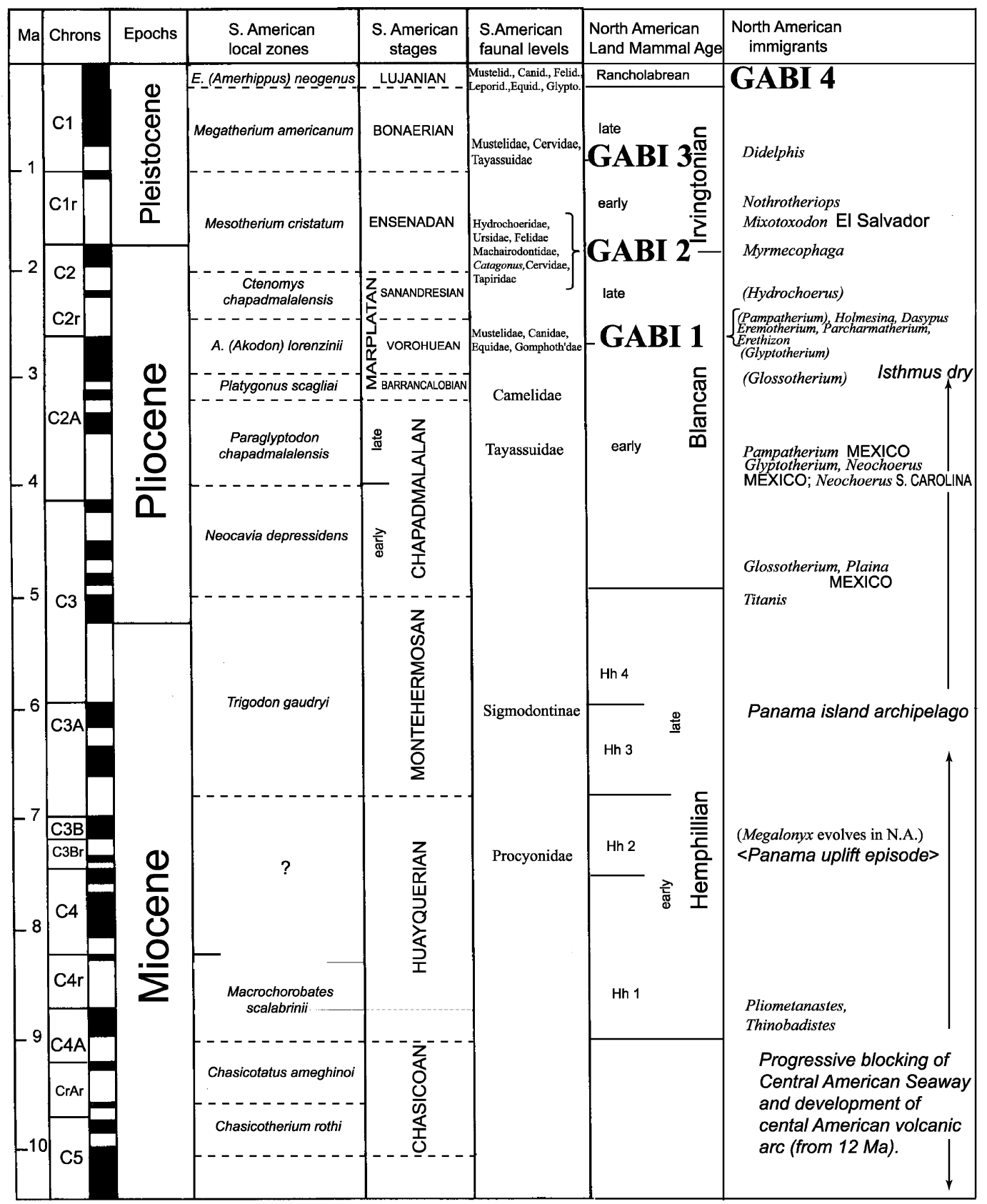

Fig. 3 General chronology of North and South American dispersal episodes, after Cione et al. (2007). Dispersal taxa to North and South America modified according to the text.

\section{Dispersal pattern}

This is updated and revised from Woodburne et al. (2006) and Cione et al. (2007), and other cited references. The discussion recognizes the fact that the South American record still is being developed in areas north of Argentina. Fig. 3 shows the overall chronology of the mammal-bearing units in North and South America, with a summary of the faunal exchanges detailed more fully in Fig. 4. The information also is outlined in Table 1, which additionally shows some of the South American taxa that were endemic results of the immigrations. The pattern shown in Fig. 4 indicates that the main pulse of the interchange began about 2.6 Ma, but there had been a number of more limited dispersals prior to that time. The earliest of these (Fig. 3) is represented by the sloths Thinobadistes and Pliometanastes found in faunas of early Hemphillian age (ca 8.5-9 Ma) in North America (Morgan 2008), derived from South American mylodontid and megalonychid ancestors, respectively. This is comparable to Webb (1976), modified to reflect the origin of Megalonyx from Pliometanastes at about $7 \mathrm{Ma}$ (Fig. 3 and McDonald and Naples 2008). In the 


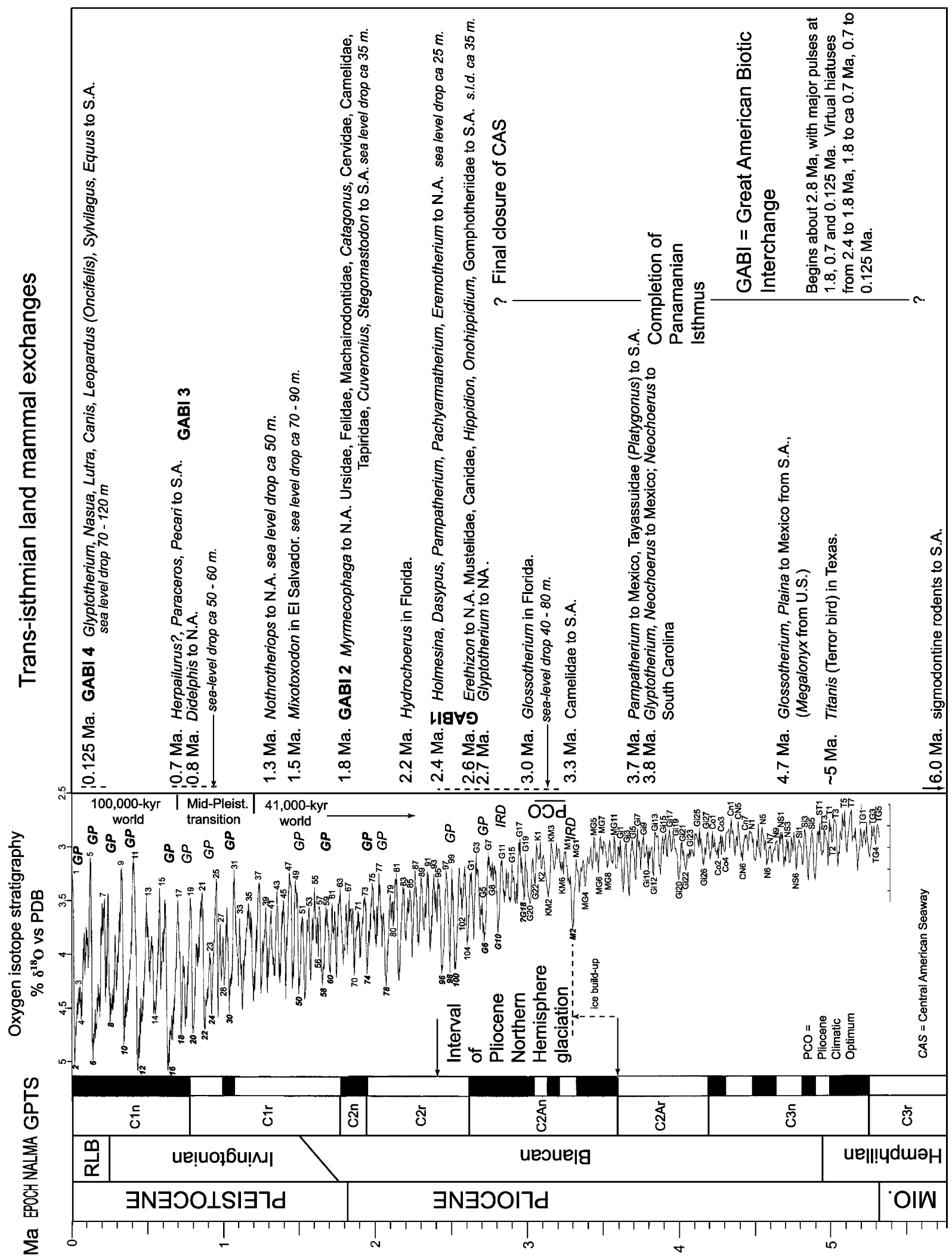

Fig. 4 Chronology of late Miocene through Pleistocene transisthmian land mammal exchanges with respect to oxygen isotope stratigraphy. Chronologic framework (Ma, Epoch, GPTS, NALMA, Oxygen isotope stratigraphy) follows Lisiecki and Raymo (2005). Interval of Pliocene Northern Hemisphere glaciation, PCO, and ice build-up, after Mudelsee and Raymo (2005). IRD=ice rafted debris after Bartoli et al. (2005). $G P=$ glacial pulse, interpreted from sea level lowstands of Fig. 7. MIS stages such as $\mathbf{1 0 0}$ (boldface) indicate those in Fig. 7 considered to reflect lowstands due to strong pulses in glaciation. Chronology and list of mammalian taxa as in text. Sigmodontine rodent as per text. Completion of Panamanian Isthmus after Coates et al. (2004), and Bartoli et al (2005). 
overall context, in which more taxa dispersed southward at the height of GABI (see below), the fact that the first elements of the interchange were from South America is noteworthy. This part of the pattern also is consistent with most newcomers to North America being, in fact, xenarthrans.

The first dispersal southward was accomplished by a procyonid carnivoran, reflected by $*$ Cyonasua $(*=$ endemic South American taxon that reflects a dispersal), at about 7.3 Ma (Procyonidae, Fig. 3; also Cione et al. 2007). This was followed by sigmodontine rodents at about $6 \mathrm{Ma}$. Verzi and Montalvo (2008) proposed that mustelid carnivorans also entered South America at about this time, but that chronology and identification have been questioned by Prevosti and Pardiñas (2009). Lindsay (2008) indicated that sigmodontine rodents (cricetids, contra murids in Webb 2006 and other papers) were well developed by the Clarendonian NALMA (ca $12 \mathrm{Ma}$ ) in North America. Forasiepi et al. (2007) pointed out that the late Huayquerian record of Cyonasua may have coincided with the last occurrence of metatherian borhyaenids and that there was effectively no direct competition between large terrestrial marsupial carnivores and the placental taxa that arrived in the early part of GABI.

The next exchanges (Figs. 3 and 4) took place at about 5.0-4.7 Ma, with the Terror Bird (Titanis) in Texas (ca 5 Ma; MacFadden et al. 2007) and two South American xenarthrans (the pampatheriid Plaina; and the mylodontid Glossotherium) in Guanajuato, Mexico (G; Fig. 1). Flynn et al. (2005) noted that Glossotherium is recorded in the early Blancan (4.7-4.8 Ma) in Mexico, but significantly later in the United States, where it persists to the Irvingtonian (McDonald and Naples 2008). Tomida (1987) documented Glossotherium in Arizona at about 3.0 Ma (Bell et al. 2004), an example of the Mexican holding pen (Figs. 3 and 4). Glossotherium is considered to have originated in South America (McDonald and Naples 2008, contra Webb 2006). Reguero et al. (2007) recorded the presence of Plaina in South American deposits of Montehermosan age (Fig. 3), possibly 5-7 Ma, and Flynn et al. (2005) indicated that the genus is known from the Guanajuato deposits about 4.7-4.8 m.y. old. Megalonyx is also known from Mexico at this time interval (McDonald and Naples 2008), which is the oldest record of the genus south of the United States.

At about 3.1-3.9 Ma, the glyptodont Glyptotherium and the hydrochoerid rodent Neochoerus are recorded in Guanajuato, Mexico (Flynn et al. 2005). On Table 1 Neochoerus is noted from the Ensenadan NALMA, at about $1.8 \mathrm{Ma}$. Whether this indicates that the genus arose in Central America and dispersed later to South America remains to be determined (Woodburne et al. 2006:97). Glyptotherium persisted at least until about $2.7 \mathrm{Ma}$, when it entered North America, possibly released from a holding pen. The original dispersal episode was followed at about 3.7 $\mathrm{Ma}$, as the pampatheriid xenarthran Pampatherium entered Mexico (Woodburne et al. 2006: 95 L) and Tayassuidae (artiodactyl peccaries) are recorded in the late Chapadmalalan SALMA in South America (Cione et al. 2007). Shortly after, at about $3.1 \mathrm{Ma}$, the peccary, Platygonus scagliai, is recorded in Argentina. Unless reflecting a second immigration, this species apparently descended from a Chapadmalalan precursor, which must have been an un-named species of that genus (see also Prevosti et al. 2006, and references cited therein). Platygonus is shown at about 3.7 Ma in South America on Table 1. Wright (1998) indicated that Platygonus is known from early late Hemphillian faunas in North America (Hh3, Fig. 3), at about $7 \mathrm{Ma}$. The former use of the hog-nosed skunk Conepatus (e.g., Webb 1985) as a Chapadmalalan immigrant has been discounted by Cione et al. (2007).

Also at about $3.8 \mathrm{Ma}$, the typically wet-temperate to tropical-adapted South American hydrochoerid rodent $\mathrm{Neo}$ choerus is recorded in South Carolina (Sanders 2002), as well as in Mexico. Neochoerus persisted in Florida (Macasphalt Shell Pit; Bell et al. 2004) and Arizona (111 Ranch L.F., Morgan 2005) at about 2.6 Ma, and survived on into the Rancholabrean in coastal localities of the southeastern United States (Morgan 2008).

At about 3.3 Ma, the North American camelid artiodactyl group is represented by the South American genus *Lama (Camelidae; Barrancalobian SALMA, Fig. 3; Cione and Tonni 1995, 2005; Cione et al. 2007). As discussed further below, the record of this savanna-adapted genus occurs within the early development of prominent Northern Hemisphere glaciation.

At 3.0 Ma, the South American mylodontid xenarthran Glossotherium is found in Arizona and Florida (Bell et al. 2004), derived from its older Mexican record (above).

GABI began in earnest (GABI 1, Figs. 3 and 4) at about 2.6-2.4 Ma, with the first major dispersal of both North American and South America taxa. This is comparable to the time of final closure of the CAS (Bartoli et al. 2005) but, as discussed below, climate change was a key factor without which such a strong interchange would not have taken place. In general, the taxa discussed here resemble those typically having been involved in the interchange by Webb (1985) and Marshall et al. (1984) at about 2.5 Ma, and as discussed by Cione et al. (2007). Regarding the South American record, Cione and Tonni (1995) and Cione et al. (2007) pointed out that the interchanges took place as a number of pulses, as did North American entrants as well, as indicated here. As noted in Figs. 3 and 4, Glyptotherium arrived in North America at about $2.7 \mathrm{Ma}$, but this is not considered part of GABI 1 due to its previous presence in Mexico (ca $3.8 \mathrm{Ma}$ ). 
Reguero et al. (2007) recorded the first occurrence of the porcupine Erethizon in South America at about 2.6 Ma, essentially coeval with its dispersal to North America. Until this update, Flynn (2008) as well as (Webb 1985, 2006, and other papers) indicated Erethizon had been introduced to North America, even though that genus or a close relative still had been unknown in South America. Flynn (2008) included in Erethizon the North American fossil species referred to ${ }^{*}$ Coendu by White (1970) that ranged from the late Blancan to Irvingtonian, the earliest record of which is the ca 2.6 Ma Wolf Ranch L.F. of Arizona (see also Harrison 1978; Albright 1999). ${ }^{*}$ Coendu remains an endemic South and Central American porcupine that is found today no farther north than Honduras (Flynn 2008).

As clarified by Cione et al. (2007), a large number of taxa dispersed to South America at this time, including a mustelid carnivoran $\left({ }^{*}\right.$ Galictis; Table 1$)$, a canid carnivoran (*Dusicyon - also known as *Pseudalopex; Prevosti 2006), and equid perissodactyls (*Hippidion, *Onohippidium; both genera have an earlier record in North America, but subsequently are indigenous to South America). López et al. (2001) add a ?gomphotheriid proboscidean. The South American elements of this dispersal are thus reflected in the Vorohuean record of the Canidae, Equidae, Mustelidae, and Gomphotheriidae in Fig. 3.

Beginning about 2.4 Ma, the pampatheriid xenarthran Pampatherium entered the United States from Mexico (a laggard from a 3.7 Ma holding pen; Morgan and Hulbert 1995; Flynn et al. 2005) along with its through-moving relative Holmesina, a dasypodid armadillo (Dasypus), a glyptodontid (Pachyarmatherium), and a megatheriid sloth (Eremotherium) (Bell et al. 2004; Morgan 2005). On Figs. 3 and 4, this is the last interval assigned to GABI 1.

As indicated in Fig. 4, four families of xenarthransDasypodidae (Dasypus), Pampatheriidae (Holmesina), Glyptodontidae (Pachyarmatherium), and Megatheriidae (Eremotherium) - and an erethizontid rodent dispersed to North America during GABI 1, with previously dispersed elements of the Pampatheriidae (Pampatherium) and Glyptodontidae (Glyptotherium) having been released from Mexico. This compares with four non-xenarthran placental families having entered South America (Mustelidae, Canidae, Equidae, and Gomphotheriidae). In that the southward contingent included two families of carnivorans as well as advanced herbivores, it can be argued that the diversity of that group is greater than the northward dispersants, as discussed further below.

An apparent gap in dispersals from 2.4 to $1.8 \mathrm{Ma}$ seems to have been a tropical holding pattern for hydrochoerid rodents. Hydrochoerus is present in Florida at about $2.2 \mathrm{Ma}$ in presumably wet conditions and might have been lingering in local sites in the Isthmian region in any case.
At approximately 1.8 Ma South America witnessed a strong dispersal pulse (GABI 2, Figs. 3 and 4) from North America. This pulse is represented in South America by the Ursidae (*Arctotherium), the felid cats Felis, Puma and Panthera, the saber-toothed cat Smilodon, the peccary Catagonus, the camels *Palaeolama and *Hemiauchenia, Cervidae (endemic representatives being the marsh deer *Epiuryceros and the South American deer *Antifer; Table 1), the tapir Tapirus, and the gomphotheriid proboscideans Stegomastodon and Cuvieronius. All of these taxa have first South American appearances in the Ensenadan SALMA (bracket, Fig. 3, and Tonni et al. 1992; Cione and Tonni 1995, 2005; MacFadden 2000; Pomi and Prevosti 2005; Soibelzon et al. 2005). In that context, *Palaeolama and *Hemiauchenia are considered endemic South American taxa subsequent to their dispersal from their congeners in North America (Honey et al. 1998; Woodburne et al. 2006). This episode also records the presence of the USA endemic mylodontid Paramylodon in Florida (Morgan 2005), and the South American vermilinguan immigrant Myrmecophaga (Morgan 2008), known from the El Golfo L.F. of Sonora, Mexico (North America) at about 1.6$1.8 \mathrm{Ma}$ (Shaw and McDonald 1987). McDonald and Naples (2008) indicated that Paramylodon descended from the North American taxon Glossotherium chapadmalalense.

Single-taxon dispersals took place at 1.5 and $1.3 \mathrm{Ma}$. Mixotoxodon is recorded from the early Pleistocene Barranca del Sisimico Local Fauna of El Salvador, along with Pteronotus (bat), Cuvieronius (gomphotheriid proboscidean), Eremotherium (megatheriid sloth), and Megalonyx and Meizonyx (megalonychid sloths). The $1.5 \mathrm{Ma}$ age is an approximation, but Webb and Perrigo (1984) considered this the earliest occurrence of Mixotoxodon in Central America. The record of Megalonyx may represent the oldest and southern-most occurrence of that genus south of Mexico. The other taxa in the Barranca del Sisimico L.F. were not involved in immigrations at this time.

The dispersal at $1.3 \mathrm{Ma}$ is represented by the megatheriid Nothrotheriops from the Leisey Shell Pit, Florida. Bell et al. (2004) considered the genus to be present in the Vallecito Creek L.F. of California, dated at about 2.1 Ma, but Morgan (2005) revised that record to the endemic Megalonyx. Morgan (2005) is followed here for the age of the Leisey Shell Pit.

At about $0.8 \mathrm{Ma}(\sim 0.8-1.0 \mathrm{Ma})$ the marsupial Didelphis entered North America (Fyllan Cave; Bell et al. 2004; Morgan 2008), likely coincident with a dispersal at about 0.7 Ma to South America by the jaguarundi *Herpailurus, the cervid *Paraceros, and the peccary *Pecari, taxa known from faunas of Bonaerian age (Mustelidae, Cervidae, and Tayassuidae, Fig. 3 and Cione and Tonni 2005; Prevosti 2006; Cione et al. 2007). This interval is dubbed 
GABI 3 (Figs. 3 and 4) in representing a bi-polar exchange of at least four taxa.

Finally, at about, or subsequent to, $0.125 \mathrm{Ma}$, a major dispersal (GABI 4, Figs. 3 and 4) to South America is recorded by the glyptodontid xenarthran Glyptotherium, the coati Nasua, the river otter *Lutra, the canid Canis, the ocelot*Leopardus (Oncifelis), the sylvilagine rabbit Sylvilagus, and the equid Equus: a relatively diverse if not balanced assemblage of Lujanian age (Mustelidae, Canidae, Felidae, Leporidae, Equidae, and Glyptodontidae, Fig. 3 and Tonni et al. 1985; Cione and Tonni 1995, 2005; Prevosti 2006; Carlini et al. 2008). Hulbert and Pratt (1998) record Leopardus from about coeval deposits in Georgia. Prevosti and Rincón (2007) also record the entry of Urocyon (gray fox) to northern South America at about $25 \mathrm{ka}$.

In summary, the GABI can be considered as a series of pulses, possibly reflecting the impact of glacial conditions in the Northern Hemisphere (see below). A major exchange (GABI 1) from 2.6 to 2.4 Ma resulted in a porcupine and variety of xenarthrans coming to North America, a group of carnivorans and equids and a gomphotheriid proboscidean to South America. The just antecedent dispersal of a camelid to South America at about 3.3 Ma likely records the earliest glacially-coeval southward dispersal of North American savanna-adapted mammals, but is not considered part of GABI 1 as defined above.

A dispersal gap from about 2.4-1.8 Ma saw limited northward ingress of a hydrochoerid rodent, possibly representing an earlier presence in an isthmian tropical holding pen.

Renewed dispersal at about 1.8 Ma (GABI 2) entailed a diversity of carnivorans, artiodactyls, a perissodactyl, and two proboscideans to South America, and a myrmecophagid xenarthran to the north.

Another gap from about 1.7-0.7 Ma saw limited dispersal to Central America by a toxodont at $1.5 \mathrm{Ma}$ and by a megatheriid sloth to North America at $1.3 \mathrm{Ma}$. GABI 3 recognizes a bi-polar exchange of an opossum at $0.8 \mathrm{Ma}$ northward and a carnivoran and two artiodactyls at $0.7 \mathrm{Ma}$ to the south. The last major dispersal, GABI 4, at about $0.125 \mathrm{Ma}$ reflected a diversity of carnivorans, a sylvilagine rabbit, the equid Equus, and a glypdodont xenarthran having dispersed to South America.

The above indicates that, overall, somewhat more mammalian genera dispersed southward (32) than northward (17, excluding the bird, Titanis), with that pattern being most sharply evident in GABI 2, 3, and 4. As indicated above, the phyletic diversity was always greater in the southern contingent, with the northern comprised mostly of xenarthrans, a minor contribution of an erethizontid rodent, two hydrochoerid rodents, and a marsupial.
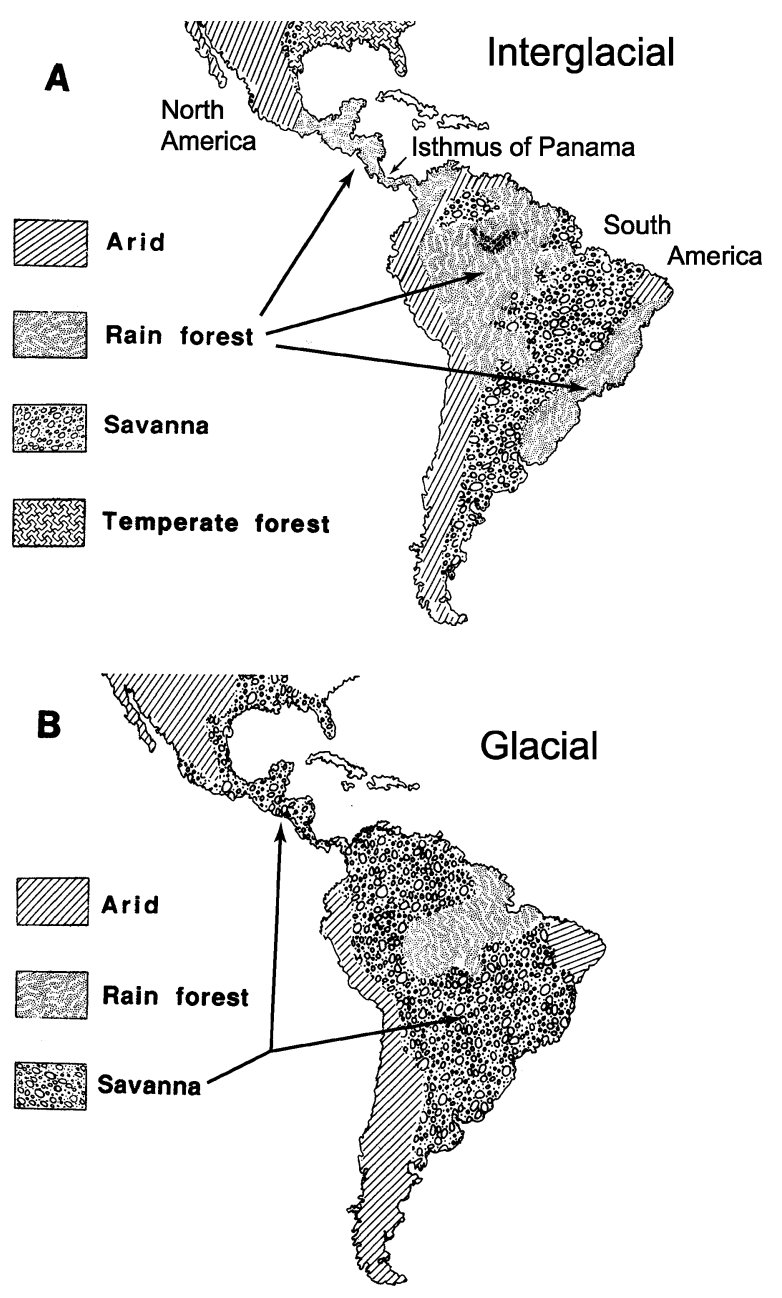

Fig. 5 Distribution of Pleistocene landscape types in North and South America. After Webb (1991: fig. 3). a. Interglacial (present-day) conditions result in rainforest habitats dominating the isthmian region, as well as in the Orinoco and Amazon basins of South America. In this situation, arid or savanna habitats of North America are completely separated from South American counterparts. b. Northern Hemisphere glacial conditions result in the preponderance of savanna and other open landscapes that allowed the extensive population of South America by North American taxa during the Great American Biotic Interchange. Note the many apparently close correlations between multi-taxon dispersal events and glacial pulses $(G P)$ in Fig. 4.

\section{Climate}

Under the above tectonic interpretation, elements of the isthmian land bridge were physically present well before the major GABI dispersals transpired, and in this context the climatic stimulus invoked by Webb (1991) is even more appropriate as identifying the major dispersal instigator. Regardless of the presence of a pathway composed at least of a series of islands, major overland dispersal of terrestrial mammalian taxa apparently did not take place until the climate was conducive to support the temperate-adapted taxa that experienced the changes in their respective home ranges. It seems strongly credible that climate was the 
primary control for the initiation (2.6-2.4 Ma; GABI 1, Figs. 3 and 4) and subsequent development of the Great American Biotic Interchange.

As indicated in Fig. 5, a glacially driven climate would have resulted in the development of savanna-like conditions in the isthmian region in contrast to the tropical rainforests of Pleistocene interglacial (and present-day) settings that would have presented (and now does present) a major ecologic barrier regardless of it being a dry-land route. The ecologic adaptations and diversity of the dispersing taxa witnessed throughout the GABI episodes are largely consistent with their having occupied a savanna environment (Webb 1991), although the floral pattern likely was not as generalized as suggested in Fig. $5 \mathrm{~b}$ (see below). Implicit in this scenario is the thesis that pre-GABI climates in Central America were essentially tropical (Graham and Dilcher 1998) even though differently constructed than at present. In contrast, the dispersals during this earlier interval lack a similarly-focused mechanism, and are perhaps more difficult to interpret.

The data in Figs. 3 and 4 indicate that in the pre-GABI interval, from about $9 \mathrm{Ma}$ to $3 \mathrm{Ma}$, South America contributed five genera in three families of xenarthrans Mylodontidae and Megatheriidae (9 Ma), Pampatheriidae and Mylodontidae (4.7 Ma), and Pampatheriidae (3.7 Ma), plus one genus of hydrochoerid rodent (3.8 Ma). This compares with a similar number of genera (4) passing southward: a procyonid carnivoran $(7.3 \mathrm{Ma})$, a sigmodontine rodent $(6.0 \mathrm{Ma})$, a peccary $(3.7 \mathrm{Ma})$, and a camel (3.3 Ma). Typically, the northward contingent was composed mostly of xenarthrans, whereas the southward group was more diverse, and even picked up a few apparently savanna-adapted genera toward the end of the interval (Platygonus, Camelidae) at, or slightly prior to, the

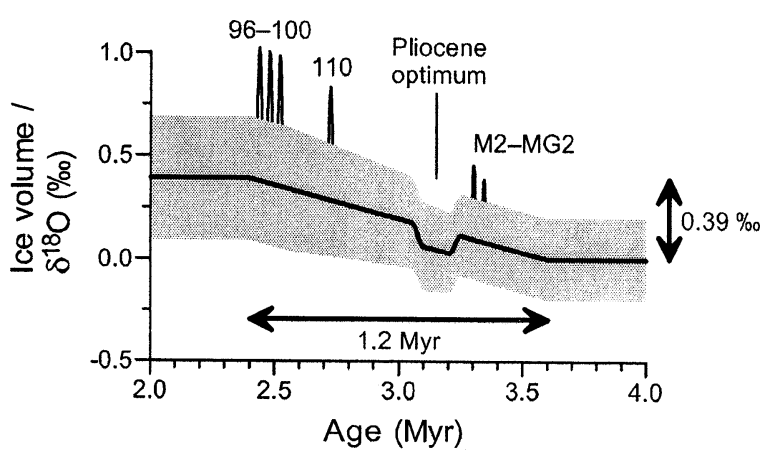

Fig. 6 Schematic portrayal of NHG climatic transition in the Pliocene after Mudelsee and Raymo (2005). NHG began about 3.6 m.y. with increase in ice volume (solid line); increase was $0.39 \%\left(\delta^{18} \mathrm{O}\right.$ equivalent). Shaded band shows $\delta^{18} \mathrm{O}$ fluctuation relative to the ice volume trend. The warm deviation from 3.25-3.0 Ma represents the Pliocene Climate Optimum. M2-MG2 (3.2 m.y.), 110 (2.7 m.y.), 96100 (2.4-2.5 m.y.) are oxygen isotope cycles showing glacial pulses. Ages are in m.y. rather than $\mathrm{Ma}$ to reflect astronomically-based chronology.
Pliocene Climatic Optimum (3.25-3.05 Ma; Mudelsee and Raymo 2005).

This interval definitely preceded both the beginning of the main episodes of the Great American Biotic Interchange and Northern Hemisphere glaciation. Whereas the general trend in global climate shows a cooling after the MidMiocene Climatic Optimum at about $15 \mathrm{Ma}$ (Zachos et al. 2001), significant pulses of NHG did not take place until about 3.3 Ma (Fig. 6 and Mudelsee and Raymo 2005). Under those conditions it is most plausible that the isthmian region supported a tropical ecosystem, at least until about 2.7 Ma, when the major episodes of NHG began in earnest.

In that context, Webb (1976) suggests that Thinobadistes and Pliometanastes likely swam across minor stretches of ocean in their northward dispersal adventures. Based on McDonald (2005) and McDonald and Naples (2008), it appears that virtually all of the xenarthrans that crossed the Panamanian isthmus to reach North America were somewhat smaller than their contemporaries and also, of the other members of their respective families, were generalists in habit and ecology rather than specialists. It also appears that the digestive system (no caecum) used by some of these xenarthrans - in contrast to many contemporary artiodactyls and other ungulates-allowed them (except for Myrmecophaga and insectivorous dasypodids) to utilize food types comparable to those of non-ruminant artiodactyls and that, hence, they were not in direct competition with either ruminant artiodactyls or proboscideans. This adaptation apparently was heightened by the low metabolic rate for xenarthrans in comparison with other mammals, and in contrast with non-ruminant peccaries and camels.

Thus, the North American xenarthran immigrants apparently succeeded by accessing ecologies not occupied by other herbivores. This is consistent with the fact that, with the exception of Eremotherium - which retained a mainly southeastern coastal distribution in the United States - other xenarthrans became widely distributed across the continent in a variety of habitats (McDonald and Naples 2008). It thus is perhaps not surprising that xenarthrans fared so successfully in trans-isthmian dispersals. It also appears instructive that the only non-xenarthran immigrants to North America were omnivorous marsupials, a porcupine, and aquatic (and probably tropically adapted) hydrochoerid rodents. It seems reasonable to suggest that these northward dispersants were ecologically gregarious.

The coincidence between tectonic uplift in Central America and the southward dispersal of Cyonasua at about 7.3 Ma has been noted above. Although not closely related to the living coati (Nasua), Cyonasua is a member of its sister-group. Both appear to be omnivorous, rather than dietarily specialized, and likely shared forested habitats (Baskin 1998; Koepfli et al. 2007). Arctonasua, the purported sister-taxon to Cyonasua (Baskin 1982, 1998), 
is found in deposits of late Barstovian through late Hemphillian age in North America with all but $A$. floridana, chiefly represented in the Great Plains (Texas, Oklahoma, Nebraska) states. A. floridana is of late Clarendonian age, from the Love Bone Bed of Florida, ca 9.5 Ma (Tedford et al. 2004), and A. eurybates is represented in the late Hemphillian, Upper Bone Valley L. F. of Florida, ca 5.5 Ma. These records suggest that species of this genus were capable of living in moist, humid conditions that likely were similar to those exploited by Cyonasua regardless of whether this genus was phyletically close to either A. floridana or A. eurybates. Note, however, that these species bracket the age of the dispersal of Cyonasua. Webb (2006) recounts the aquatic expertise of raccoons (and living sloths).

In this general context the ca $6.0 \mathrm{Ma}$ dispersal of a sigmodontine rodent to South America was considered sufficiently remarkable climatically that Verzi and Montalvo (2008) chose to align this record with a cool spike in the MIS chronology. The associated mammalian fauna includes a diversity of marsupials, xenarthrans, litopterns, and hystricomorph rodents considered to have lived in relatively cool, arid, and open conditions in southern, in contrast to more tropical settings of northern, South America. Whereas this interpretation is highly interesting, the actual age of the faunas considered by Verzi and Montalvo (2008) has been questioned and discounted by Prevosti and Pardiñas (2009), so whether the cooler climates envisioned by Verzi and Montalvo (2008) can be applied to the basic sigmodontine immigration in Central America remains to be seen. Whether or not comparably cooler and drier conditions were present in Central America at the 4.7, 3.7, and 3.3 Ma dispersal events (Fig. 4) also remains to be ascertained, but the southward dispersal of a peccary at 3.7 $\mathrm{Ma}$ and a camel at about 3.3-3.1 $\mathrm{Ma}$ is perhaps suggestive of at least drier environments. This peccary is well represented in continental deposits of Hemphillian and Blancan age in the North American Great Plains region (Wright 1998) and savanna-like ecologies (Prothero 1998; Janis et al. 1998; Mio-Pliocene Chronofauna), and appears to have been the earliest savanna-adapted element to have traversed the isthmus to South America. Whereas the northward dispersals of Pampatherium and Glyptotherium might be ascribed to the adventurous dispersal capabilities of xenarthrans, the $3.8 \mathrm{Ma}$ entry of Neochoerus to Mexico (and South Carolina) certainly carries connotations of at least local humidity, as well, reflective of a diversity of habitats.

Webb (1991) noted that prior to the advent of Northern Hemisphere glaciation, faunal exchanges between North and South America had been relatively balanced numerically, if not necessarily ecologically. This is consistent with the numbers of taxa discussed above, with four genera in as many families having dispersed southward from the Huayquerian to Barrancalobian SALMAs, in comparison to six genera in four families going northward (Fig. 3) during an equivalent interval.

Similarly, about the same number of genera moved southward (five) as northward (five) in GABI 1, from 2.6-2.4 Ma, distributed among a mustelid, a canid, two equids and a gomphotheriid moving southward, and a porcupine, an armadillo, a pampatheriid, a glyptodontid, and a megatheriid xenarthran going north. Of those moving northward at $2.4 \mathrm{Ma}$, the still living Dasypus now inhabits warm-temperate to subtropical districts in the Gulf and Atlantic Coastal plains and formerly occurred as far north as Iowa in the Pleistocene (Morgan 2008). Overall, the GABI 1 interval appears to include mostly savanna- (or at least non-tropical) adapted taxa As indicated on Fig. 4, this interval coincides with the first episode of Northern Hemisphere glaciation after the Pliocene Climatic Optimum, with major pulses at 3.3, 2.7 and 2.5 Ma (also Figs. 6 and 7).

The sole hydrochoerid immigrant to Florida at $2.2 \mathrm{Ma}$ likely reflects the presence of humid, and potentially tropical, conditions in Central America with the family having been present there at least by $3.8 \mathrm{Ma}$ (the family is present as early as the Chasicoan SALMA in South America; Fig. 3 and Cione et al. 2000). As summarized by Morgan (2008) Hydrochoerus persists into the late Pleistocene of wet temperate to tropical North America (South Carolina, Florida) as well as Honduras and Mexico, but is not found at the present time north of southern Panama.

GABI 2 at 1.8 Ma shows the pattern typical of Webb (1991), with a much greater number (11) and diversity of taxa moving southward than the reverse (one xenarthran), and the presence of numerous glacial pulses at about this time (Fig. 4) is consistent with his proposal that the dispersals reflected episodes of Northern Hemisphere glaciation. The pattern in Fig. 4 suggests (along with Zachos et al. 2001) continued climatic cooling between the intervals described as GABI 1 and GABI 2, which apparently resulted in a much stronger development of savanna-like conditions at that time (see discussion of Central American plants below). This seems to be reflected in the strong ecologic diversity displayed by the southern contingent of GABI 2.

If the pattern in GABI 1 is consistent with the exchange of taxa being coeval with major Northern Hemisphere glaciation, that of GABI 2 would appear to be even more so, based on the strength of its southward contingent and depending on the actual age of the $1.8 \mathrm{Ma}$ dispersal relative to the major glacial pulses (GP) shown on Fig. 4. A similar suggestion can be made 


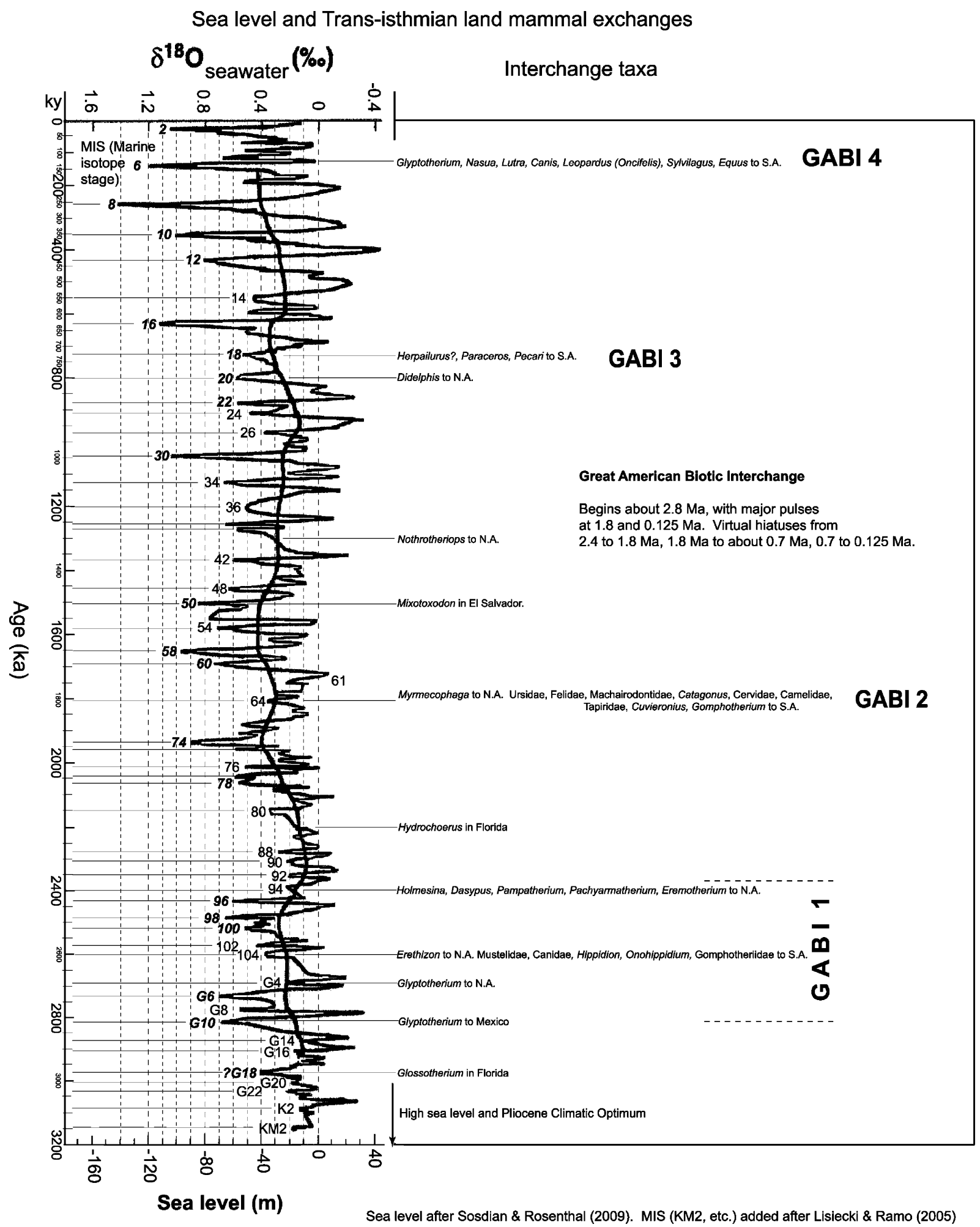

Fig. 7 Chronology of sea level changes during the past 3.2 Ma. After Sosdian and Rosenthal (2009), with MIS units after Lisiecki and Raymo (2005), and vertebrate exchanges added.

relative to GABI 3, with a number of glacial pulses from MIS 16 to MIS 20. GABI 4 is a strong example of the pattern espoused by Webb (1991), with a virtual absence of northward dispersants versus a strong diversity of savanna-adapted taxa moving southward. The interval beginning with GABI 2 and continuing through GABI 4 is unusual in not having witnessed northward incursions of tropical taxa perhaps attesting to overall cooler 
conditions regardless of any potential interglacial influence during the NHG. The 1.5 Ma immigration of Mixotoxodon as far north as El Salvador appears to reflect South American savanna affinities.

Regarding the NHG, Bartoli et al. (2005) consider the beginning of severe Northern Hemisphere glaciation to have been aided by the final closure of the Central American Seaway (CAS), with the effect that Pacific Ocean waters no longer advected into the Atlantic Ocean. Bartoli et al. (2005) proposed that closure of the CAS was virtually complete by $2.8 \mathrm{Ma}$; they noted that ice-rafted debris (IRD in Fig. 4), generally considered to reflect major continental glaciation, is recorded as early as $2.82 \mathrm{Ma}$, and pointed out that a major expansion in global ice volume occurred during an interval from 2.93-2.82 Ma (MIS G16-G10; Fig. 4). Under these scenarios, the climatic as well as CAS closure factors were in place prior to the apparent beginning of the GABI.

This is compatible with conclusions of Mudelsee and Raymo (2005), who portray a gradual build-up in ice volume from 4.0 to $2.0 \mathrm{Ma}$ (Fig. 6), with the NHG pulses beginning at about 3.6 m.y., and the first glacial event (MIS M2 and MG2) recorded at about 3.3 m.y. Stage M2 apparently reflects a stronger glaciation than stage MG2, has a stronger $\delta^{18} \mathrm{O}$ excursion (Fig. 4) and a strong IRD record, as well.

In distinct contrast, the Pliocene Climatic Optimum from about 3.25-3.05 m.y. saw a rise in sea level and deglaciation. Cronin and Dowsett (1991) indicated that at 3.1 Ma, the Atlantic coast shoreline was $35 \pm 18 \mathrm{~m}$ higher than at present (also Fig. 7). This secular reversal, however, is part of an overall pattern of gradual cooling of the Northern Hemisphere. Mudelsee and Raymo (2005) indicated that further glaciations occurred at 2.7 m.y. (compatible with the second NHG and strong IRD pulse of Bartoli et al. 2005), and also at 2.4-2.5 m.y., with strong oxygen isotope excursions shown at MIS 100-96 (Fig. 4). Figure 7 indicates that sea level lowstands ranging from about $50 \mathrm{~m}-75 \mathrm{~m}$ occurred at MIS 100-96 as well, indicated here as a glacial pulse $(G P)$ on Fig. 4. In summary, the Mudelsee and Raymo (2005) compilation indicates that not only was the onset of Northern Hemisphere glaciation part of a gradual process, but also that the shallowing of the CAS had been underway for several millions of years (also Coates et al. 2004), and was unlikely to have been the root cause of the NHG. Lawrence et al. (2009) concurred with the gradual development of NHG and demonstrated the prominence of IRDs in the glacial record subsequent to about 2.7 Ma. It also seems clear from Lawrence et al. (2009: Fig. 2) that their IRD record closely parallels the intervals labeled as $G P$ on Fig. 4 of the present article.

\section{Sea level}

Figure 7 shows sea level curves interpreted by Sosdian and Rosenthal (2009), with MIS units added from Lisecki and Raymo (2005) and times of trans-isthmian land mammal exchange from Fig. 4. It is recognized that the correlation of the terrestrial mammals is less precise and thus less accurate than the MIS chronology. Still, the ages of the land mammal events were developed independently of any consideration of the MIS or sea level scales, so the apparent alignment of many of those events with strong MIS excursions or drops in sea level is at least compatible with the thesis of Webb (1991) that trans-isthmian dispersals that involved mammals having an affinity with savanna-like environments most likely transpired during times of Northern Hemisphere glaciations (Fig. 5). It is possible that at least some of the pre-GABI dispersals were aided by cooler, if not glaciallyassociated, conditions with respect to their impact on vegetation patterns.

The pattern in Fig. 7 suggests that, subject to strong departures in some cases, mean sea level fluctuated within a range of -10 to $-40 \mathrm{~m}$ during the past $3.2 \mathrm{Ma}$, with an eventual drop toward the present. It appears that significant episodes of mean lowstand occurred at about 2.5, 1.9, 1.6, 0.7, and 0.1 Ma. The coincidence in timing between these ages and those of the dispersals shown on those figures is striking, even after the Isthmus of Panama is considered to have been closed. It is tempting to suggest that increased development of coastal plain settings during lowstand intervals contributed to the successful overland dispersals, in addition to general climatic influence. This is discussed further below.

\section{Plants and ecologies}

Plant megafossils apparently are not well represented in Central America (and Mexico). Graham (1998) and a series of publications (Graham and Dilcher, 1998; Graham 1999, 2010; Burnham and Graham 1999) provided seminal studies and discussions regarding the Neogene pollen and spores from this region. Even though the records reported upon are derived from lowland swamps and comparable settings, the discussions also provide insight on the plant community composition at higher elevations. Central America is presently typified by its tropical rain forest (Fig. 5), but many plant communities of Miocene, Pliocene, and Pleistocene ages have different compositions, as discussed below. A major factor as regards GABI is the virtual absence of any fossil record of early Pleistocene floras. Therefore, the following begins with a Pliocene background for an interpretation of what was a likely floral 
Fig. 8 Location of Neogene floras of Central America. After Graham and Dilcher (1998: fig. 30).

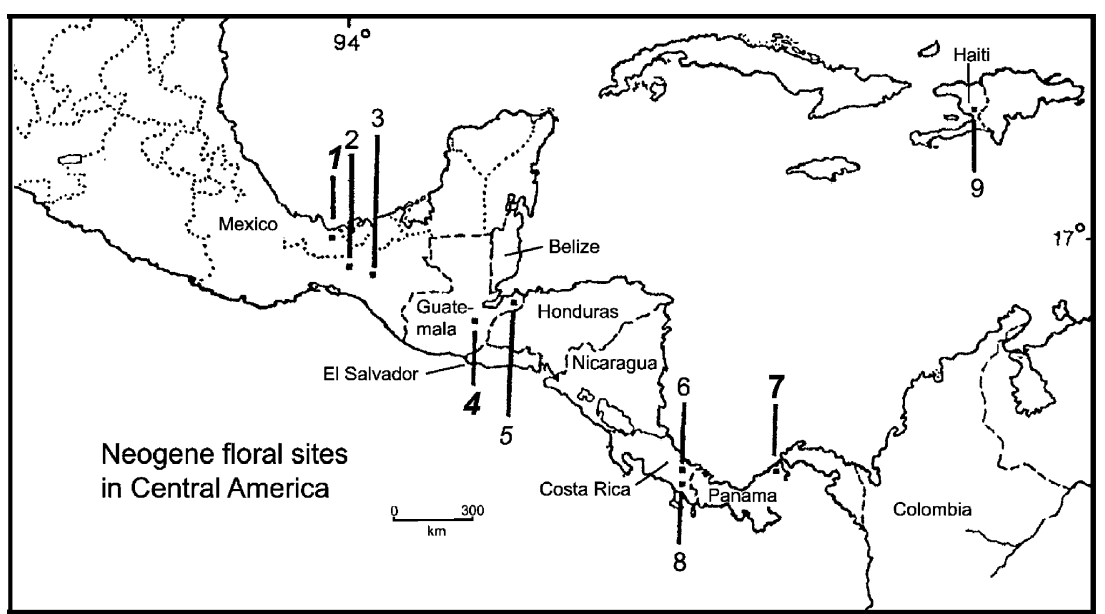

Pliocene: Paraje Solo (1); Herreria (5), Rio Banano (6) Mio-Pliocene: Artibonite (9), Gatun (7), Padre Miguel (4) Mid Miocene: Ixtapa (2), Mendez (2)

Early Miocene: Cucaracha, Culebra, La Bocha (7), Uscari (8), La Quinta (3)

bold $=$ northern temperate elements; italic = no lowland temperate rainforest (also 1 and 4 ).

Sites affiliated with diverse topography are (1), (4) and (7, Gatun). Other sites record lowland/lignite associations. and environmental scenario during the Pleistocene, discussed subsequently.

Graham and Dilcher (1998) surveyed a number of Neogene plant communities from Central America, and indicated that the region supported a tropical rain forest during the Miocene and into the Pliocene. These conditions began to change about in the Pliocene. The coastal Paraje Solo flora, SE Veracruz, Mexico (Fig. 8) shows evidence of at least local cooling (presence of Picea) and lowering of ecotones, perhaps due to the effects of local upwelling in the adjacent ocean (Graham 1973, 1976; Akers 1979). In any case the rainforest association was disrupted in this area at about $4-5 \mathrm{Ma}$ (the palynoflora is associated with strata that yield Plantkic Foraminiferal Zone N19; chronology follows Lourens et al. 2004). Farther south, in inland Guatemala, the Padre Miguel flora at about 7 Ma contains a sedge marsh association with grasses and composites along with a pike-oak temperate forest (Alfaroa-Oreomunnea, Juglans, Ulmus) and possibly a cool-temperate forest (Picea, Pinus, Quercus) in upland settings. Another Guatemalan plant community in its southeastern coast, the Herrería flora, about 3.1 Ma (Fig. 8), reflects a mangrove setting and surrounding swampy conditions. Individually and collectively these plant communities contrast with the others shown on Fig. 8 in diverging from the otherwise typical lowland rainforest of the region, and suggest a distinct level of diversity. In that the region had achieved nearly its present elevation and topography by about this time, it is plausible that the current eastern moist versus a western drier distinction also was manifested, at least in the Panamanian district.

Another aspect of floral change is shown by the first occurrence of northern temperate elements in these Central
American settings. Graham and Dilcher (1998) indicated that the Paraje Solo flora (ca 4-5 Ma) records the appearance of Abies, Picea, Pinus, Alnus, Celtis, Juglans, Liquidambar, Myrica, Populus, Quercus and Ulmus, whereas the Padre Miguel flora, farther south and older (about $7 \mathrm{Ma}$ ), contains even earlier records of Picea, Pinus, Juglans, Quercus, and Ulmus. In fact, the approximately coeval Gatun flora of Panama records an even more distant record of Ulmus.

From these examples, it appears that the typical Neogene lowland tropical rainforest of Central America underwent certain degrees of alteration toward the end of the Miocene and possible cooling or drying as suggested by the incursion of temperate elements and potentially compatible with the late Pliocene land mammal dispersals discussed above. A more coherent pattern is shown at the nearly opposite end of the Neogene/Quaternary interval, as summarized by Piperno (2006), with inferences that this pattern also was manifested in earlier parts of the Pleistocene.

Currently, the Central American lowlands are humid areas. Figure 9, however, shows a reconstruction of the vegetation between 20,000 and 10,500 ybp, including the time of the Last Glacial Maximum (LGM; 18,000 ypb). By this time Central America had achieved its full tectonic uplift (Piperno 2006). Note especially on the Caribbean side the increased coastal area afforded by maximum lowering of sea level. Such then-exposed areas mostly lie adjacent to the thorn woodland, low scrub, and wooded savanna vegetation (type 3 on Fig. 9) but, also in Honduras and Nicaragua, adjacent to forests that were significantly drier than at present, but still moist enough to support that type of forest (type 1 on Fig. 9). These floral associations 


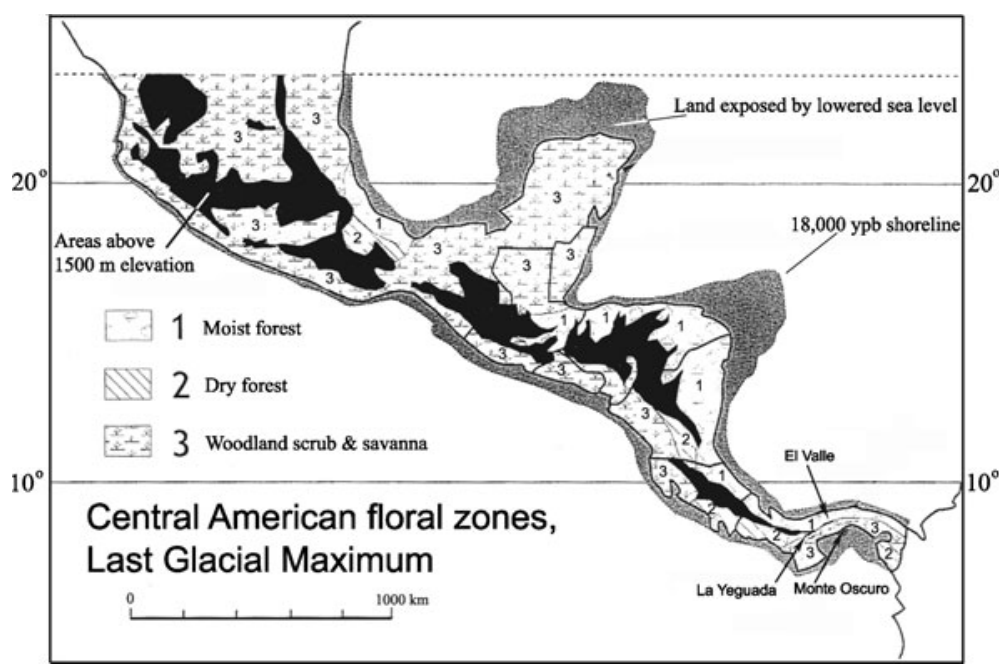

Fig. 9 Reconstruction of distribution of lowland Neotropical forest associations at the Last Glacial Maximum (18,000 ybp). After Piperno (2006: fig. 1). Gray areas indicate land exposed by lowered Pleistocene sea level during maximum glacial advance. Black areas are elevations above $1,500 \mathrm{~m}$. 1. Largely unbroken moist forest, often with a mixture of present-day high-elevation and lowland forest elements. In some areas montane forest elements (Podocarpus, Quercus, Alnus, Ilex) were conspicuous. Annual precipitation less

reflected climates that were significantly drier and cooler than at present, with surface temperatures $4^{0} \mathrm{C}-7^{0} \mathrm{C}$ lower than now, and forest canopies possibly more open than at present due to lower levels of atmospheric $\mathrm{CO}_{2}$ (Piperno 2006). Rainfall was less, possibly by $30 \%-50 \%$.

The general conditions shown on Fig. 9 persisted until about 10,500 yrs ago, which indicates that the modern lowland tropical forest of Central America did not develop until after that time (also Leyden 1984). Piperno (2006) noted that even today, the flora of western (Pacific) coastal Panama is a deciduous tropical forest living under fairly dry conditions, which, in the above late Pleistocene reconstruction, was the thorn woodland, low scrub, and wooded savanna association (type 3, Fig. 1), and consisted of many grasses, sedges, and herbaceous plants, along with the archetypal savanna indicator shrub or small tree, Curatella americana. The grasses (short and tall) used the $\mathrm{C}_{4}$ photosynthetic pathway, indicative of a dry and open landscape. Palms adapted to dry land habitats also were present. Modern deciduous trees were present only sparingly, likely along watercourses. Rainfall was reduced by $35 \%$. Piperno (2006) suggested that much of the Panamanian land bridge at this time likely was a dry open habitat, but perhaps not exactly a savanna.

Middle-elevation Panamanian late Pleistocene sites (such as La Yeguada, El Valle, Fig. 9) then as now occur at 500-650 $\mathrm{m}$. The Pleistocene vegetation was composed of a forest with trees that nowadays live at $1500 \mathrm{~m}$, but at that time had descended downslope by $800-1200 \mathrm{~m}$, than at present, but sufficient to support a forest. 2. Forest containing drier elements than typical of the present. High-elevation forest elements occur in moister areas of the zone. 3. Mostly undifferentiated thorn woodland, low scrub, and wooded savanna vegetation. Some regions (such as Guatemala) with temperate elements (Juniperus). Areas that presently receive $>2000 \mathrm{~mm}$ annual rainfall may still have supported a drier forest, as in $\mathbf{2}$. River- and stream-side locations supported a forest.

compatible with the dry climate indicated by enclosing sediments (illite clays), as compared to the present 3-4 m annual precipitation.

Piperno (2006) characterized the Pleistocene lowland Neotropical climate as being substantially drier and cooler than at present, as a result of a peculiar combination of low temperature, low precipitation, and low atmospheric $\mathrm{CO}_{2}$. Areas having what is now arboreal forest vegetation supported herbaceous types instead. Some upland areas still would have been moist enough to support $C_{3}$ plants, but in general drier-adapted $\mathrm{C}_{4}$ grasses prevailed. In situations where the present forest exists in high rainfall zones, the late Pleistocene flora was a savanna/thorny scrub association. The modern flora thus is not analogous to that of the late Pleistocene, and the latter flora contained associations of taxa not presently found together. Forest elements now found at elevations at or above $1500 \mathrm{~m}$ descended to much lower elevations (ca 800-1200 m) in the late Pleistocene.

Piperno (2006) noted that, on average, glacial periods last four to five times longer than interglacials, so during the past ca 2 m.y., plants and animals of Central America spent over $80 \%$ of their time in, and must have been adapted to, the above-summarized climatic conditions. The modern closed-canopy forests apparently represent those typical of the short-term interglacial floral associations, whereas those of the more prevalent glacial conditions are not like modern floras, and contain combinations of species not presently found together. In that sense, the glacial floras 


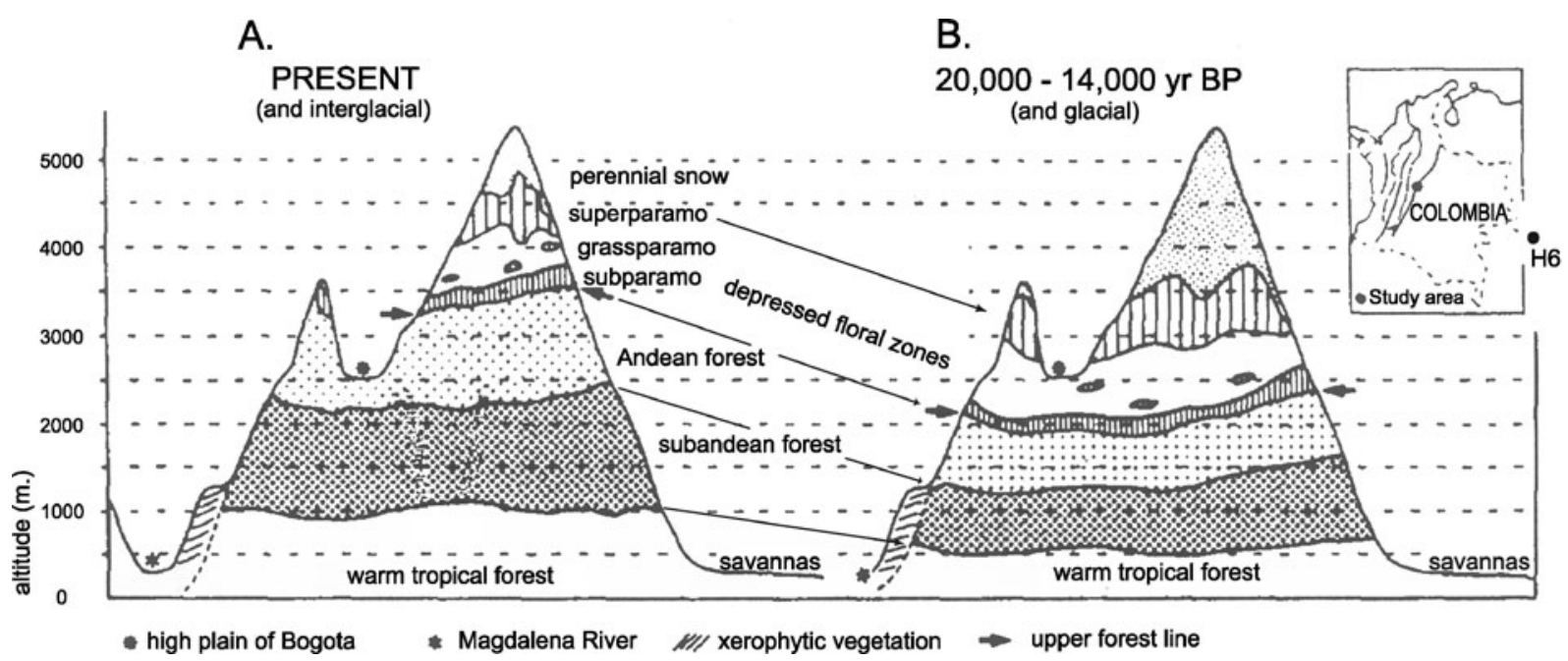

Fig. 10 Schematic representation of present-day a and last glacial b altitudinal distribution of the zonal vegetation belts in the Colombian Eastern Cordillera. After Andriessen et al. (1993: fig. 6). H6 in inset map=Hill of Six Lakes, Brazil (Bush et. al. 2004).

are not analogous to those of the present. As indicated by Bush et al. (2004) for Brazil, the pre-modern Pleistocene floras there contain associations of elements not found together today, and also represent 'non-analog' forests. This appears to be comparable to the situation in Central America and, overall, the general patterns are similar. In this context it seems reasonable to project deeper into the early Pleistocene the environmental setting and composition of the late Pleistocene floras of the region, with implications for similar climatic conditions during those older times.

It thus appears that, at the very least, conditions amenable to the dispersal of non tropical-adapted land mammals must have predominated in the Pleistocene of Central America, as well as Amazonia (i.e., Andreissen et al. 1993; below). The increased area of at least dry and open, if not completely savanna-type, environments along coastal Central America during times of decreased sea level must have played a part in facilitating GABI dispersals across the region. Whereas the early Pleistocene record of the strong onset of cooler, glacial conditions seen at Bogotá, Colombia (Andreissen et al. 1993), is not yet recorded in Central America, the Colombian record validates the above proposed projection of late Pleistocene conditions into the earlier part of the epoch, which must have affected Central America, as well.

Andreissen et al. (1993) summarized the palynology and climatic implications of extensive cores drilled in the vicinity of Bogotá, Colombia (Fig. 10) at an elevation of about $2500 \mathrm{~m}$. In contrast to the record in much of Amazonia, as well as Central America, the sequence in the cores, Funza I and Funza II, extends nearly continuously from the Pliocene through the Pleistocene, and records the climatic and tectonic conditions that were in effect during that interval. Funza I core is $357 \mathrm{~m}$ deep, Funza II, $586 \mathrm{~m}$ deep.

The interval between 541 and $586 \mathrm{~m}$ in Funza II has few pollen grains, but in the interval between 465 and $540 \mathrm{~m}$ palynofloras show high arboreal percentages and a warmer climate than subsequent parts of the core. The open character of the Andean forest is indicated by high percentages of arboreal taxa (Ilex, Rapanea, Myrica, Eugenia, plus the shrub Borreria, and high maxima of Graminae).

At $465 \mathrm{~m}$ in Funza II (and $357 \mathrm{~m}$ in Funza I) pollen indicate that conditions became much colder, and the Bogotá basin became alternately covered with Andean forest and open paramo (basically high country tundra) vegetation. The age of this level is estimated at $2.7 \mathrm{Ma}$, near an ash at horizon $506 \mathrm{~m}$ dated at $2.7 \pm 0.63 \mathrm{Ma}$. The climatic conditions recorded here represent the beginning of global glacial influence in this part of Colombia, and was accompanied by the onset of mountain glaciation around Bogotá. Interestingly, the onset of glaciation here fits well with the later part of NHG and onset of GABI I, as discussed above.

The interval between 320 and $357 \mathrm{~m}$ (Funza I) or 320 $465 \mathrm{~m}$ (Funza II) yields alternate indications of cold and warm climates considered to reflect major pulses of glaciation in the vicinity of Bogotá. At $233 \mathrm{~m}$ in both Funza cores, the palynofloral record indicates that climatic oscillations became longer and of greater amplitude. The upper $233 \mathrm{~m}$ in these cores is interpreted as reflecting ten major climatic cycles, apparently beginning with MIS 23 at about 0.9 Ma (Lisecki and Raymo 2005) and extending to MIS 3 at about $0.05 \mathrm{Ma}(50 \mathrm{ka})$. During these cold episodes, the forest line shifted between about 3400 and $1800 \mathrm{~m}$ (arrows on Fig. 10), to follow a decrease of mean annual temperature from $15^{\circ} \mathrm{C}$ to about $6{ }^{\circ} \mathrm{C}$. 
Based on the taxonomy of the units, Andreissen et al. (1993) arranged the succession into biozones. In Biozone I, which ranges in age from about 5.0 Ma to about 4.2 Ma, the plant community consists of lower elevation tropical vegetation. Hedyosmum, a northern taxon, dispersed into the region at this time.

Biozone II ranges in age from about 4.2 Ma to $3.2 \mathrm{Ma}$, and reflects the presence of tropical to sub-Andean vegetation at relatively low elevations. The floras previously characteristic of the lowlands were replaced by those from intermediate altitudes. Floras indicate a lower tropical to lower sub-Andean forest belt, between ca 1,000 and $1,500 \mathrm{~m}$, as at present (Fig. 10a). Hedyosmum is present, but Myrica still absent.

Biozone III, of 3.2-2.5 Ma is represented by an upper sub-Andean vegetation, and continues to reflect communities characteristic of intermediate altitudes. Myrica disperses into the region. Note that, as discussed above, the Paraje Solo flora (ca 4-5 Ma) of Mexico contains the first record of Myrica in Central America (also as summarized in Graham 1999).

Biozone IV ranges from about 2.5 Ma to $1.2 \mathrm{Ma}$. In the lower part, plants of Andean type predominate, but in the upper part of the section these alternate with paramo vegetation, and show a consistently high representation of Borreria. The Biozone IV flora is of high-altitude type, and its upper part begins to show the alternating vegetation types reflective of cool and warmer climates and Pleistocene glaciations.

Biozones V-VII range from 1.2 Ma to $0.2 \mathrm{Ma}$, and contain vegetation that alternates between cool and warm climates considered to be related to major Quaternary climatic changes. Alnus disperses at beginning of biozone VI, Quercus at beginning of biozone VII. Biozone V begins at about 1.2 Ma, Biozone VI at ca 0.8 Ma, and Biozone VII at about 0.2 Ma. Note that the Padre Miguel flora of Guatemala contains the first Central American record of Quercus at about $7 \mathrm{Ma}$ (discussed above).

Tectonic activity in the region is related to Andean uplift (Andreissen et al. 1993). The sediments associated with Biozone I reflect ongoing uplift, and the presence of tropical lowland forests with extensive stands of Mauritia. Biozone II reflects the final Andean uplift in this region.

As indicated above, Myrica dispersed into the region in Biozone III, prior to Pleistocene glaciations, but Alnus still is absent. The associated plants reflect an upper subAndean forest, which would have a modern elevation of about 2,200 m (Fig. 10a). By the early part of Biozone IV (ca 2.5-1.8 Ma), the Bogotá area (black dot in valley, Fig. 10a, b) supported an Andean forest belt that would occur at a modern elevation of about 2,600 m (Fig. 10a). Beginning with the later part of Biozone IV and on into biozones V-VII, the Pleistocene changes in climatic conditions resulted in downward altitudinal shifts of vegetation belts along the Cordillera. Paramo vegetation dominated during glacial conditions in the Bogotá district. As at present (Fig. 10a), Andean forests returned to this area during interglacial intervals. Mountain glaciers were present in the glacial times. Quercus entered the record in Biozone VII, likely at 200,000 yrs.

In summary, the Colombian succession records the presence of an open Andean forest that lived under a warm climate at the elevation of Bogotá in the late Pliocene. In the Pleistocene the situation changed markedly in which plants of high-altitude character descended several hundred kilometers to co-exist with lowland elements under much cooler conditions, with mean annual temperatures near $6^{0} \mathrm{C}$ in contrast to the current $14^{\circ} \mathrm{C}$. The cool versus warmer pattern is manifested throughout the Pleistocene in these cores and provides empirical demonstration of the older, as well as late, Pleistocene age of such changes. The Colombian record gives credence to the above supposition that late Pleistocene floral configurations in Central America may be projected into earlier times.

Bush et al. (2004) reported on a pollen succession derived from cores drilled in the Hill of Six Lakes district at an elevation of about $300 \mathrm{~m}$ in the Amazon Plain of northwestern Brazil (H6 on inset map of Fig. 10). The site thus represents conditions that occurred at lowland settings in this part of Amazonia. A record developed from three drilled cores extends to about 140,000 yrs and records at least two major glacial cycles.

The results indicate the Hill of Six Lakes region supported a mesic lowland forest that became infiltrated with montane elements during the last two glacial cycles, as a result of major climatic cooling. The arrival and departure of these montane elements occurred in the context of a stable backdrop of a lowland forest. The pollen in the cores indicate that upland elements descended into the lowland environment, with the amount of descent being 800-900 m relative to the modern upland setting. The development of these glacially-timed non-analog mixed lowland and montane communities was in response to the periodic cooling of mean annual temperatures by $5-6{ }^{\circ} \mathrm{C}$. It appears that the indigenous lowland flora was able to withstand the temperature changes that drove the montane taxa to lower elevations.

From the examples cited here, it appears that Pleistocene cooling from Central America to Amazonia was on the order of $9^{\circ} \mathrm{C}$ to $6^{\circ} \mathrm{C}$, respectively, and was the greatest cause of environmental and floral change, regardless of the potential effects of diminished levels of $\mathrm{CO}_{2}$ or rainfall. The effect in Brazil was to periodically lower the elevation at which montane forests existed into those areas where lowland mesic forests already were present, and which remained under the new circumstances. This pattern, over 
the past 140,000 yrs in the Hill of Six Lakes, Brazil, is comparable to that seen in the temporally more extensive record in the Bogotá plain of Colombia (Andreissen et al. 1993). If these comparisons are used as a model, it suggests that the late Pleistocene floral configurations reconstructed in Central America by Piperno (2006) also can be extended to glacial conditions earlier in the Pleistocene of that region.

An interesting aspect of Fig. 10 is the location of savanna floras in the low, coastal regions of Colombia, comparable to their setting in Central America (Fig. 9). Floral changes in Central America include the emergence of a broader coastal region at times of lowered sea level that nominally would be expected to support savanna-like ecologies, based on those that are reconstructed as lying adjacent to the coast at that time. Graham and Dilcher (1998) consider it unlikely that any given floral association formed a through-going avenue across the whole of Central America during the Pleistocene. Still, it appears that an expanded coastal environment during the $80 \%$ of the Pleistocene occupied by glacial conditions would have supplied at least one of the avenues in support of GABI dispersals.

\section{Holding pens and dispersal times}

Flynn et al. (2005) demonstrated numerous cases in which taxa considered to be part of the GABI phenomenon occurred earlier in Guanajuato, Mexico, than in the United States, and Woodburne et al. (2006) reviewed this in the context of other instances that demonstrate or suggest the strong role played by the Mexican-Central American region as a center of cladogenesis for diverse mammalian groups in the Neogene. In the present report, the holding-pen aspect of this situation has been emphasized. The pattern mostly involves various xenarthrans moving northward, and results in an apparent embargo on border crossing that lasted as long as 1.7 m.y. (Glossotherium) to 1.3 m.y. (Pampatherium) and 1.1 m.y. (Glyptotherium). It may turn out that Neochoerus entered South America at about 1.8 Ma, well after its earlier presence in Central America is suggested by a 3.8 Ma record in Mexico and South Carolina. Examples of this order of magnitude, for which there is no obvious physical, geologic, or biologic cause, raise the question of the fidelity of the paleontological record, also voiced by Verzi and Montalvo (2008), as to the actual age of dispersals when found at their eventual endpoints (see also Dispersal Lag; Woodburne and Swisher 1995). In this regard it is encouraging that the Neogene fossil mammal record for Central America is improving (Cisneros 2008; Lucas 2008; Lucas et al. 2008), which may further aid in addressing the question of the times when mammals actually transgressed the Panamanian Isthmus.
Campbell et al. (2000, 2001, 2010) have described gomphotheriid fossils identified as Amahuacatherium peruvium from deposits in the Cerro Colorado region of Peru, and have discussed stratigraphic, radioistopic and paleomagnetic data that collectively form the basis for assigning an age of somewhat greater than $9 \mathrm{Ma}$ to these remains. If accurate, this would place the entry of gomphotheriid proboscideans in South America substantially earlier than their currently understood record of about $1.8 \mathrm{Ma}$ (above). In those papers Campbell et al. also assert that at least one species of peccary and a camel co-occur with Amahuacatherium, in which case that would also pre-date significantly the otherwise known first occurrences of these taxa in South America, 3.7 and 3.4 Ma, respectively.

The above hypotheses include a geological perspective that favors a fairly simple and regionally more or less uniform Neogene stratigraphy of western Amazonia. That proposal is challenged to a large degree by papers of Latrubesse et al. $(2007,2010)$ that address evidence suggesting a more complicated, terrace complex series of stratigraphic relations for Neogene deposits across western Amazonia. It is possible that the beds that overlie Amahuacatherium at Cerro Colorado are not as old as conventionally thought, which also might elevate the age of Amahuacatherium, itself.

Whereas the a number of the diverse demonstrations and interpretations presented by Campbell et al. (2000, 2001, 2010) have merit, it still is not clear how a proposed 9+ Ma record of gomphotheriids, peccaries, and camels in Peru can be reconciled with their essential absence for $6+$ m.y. in the fossil mammal record of all of South America. The Amahuacatherium situation remains unresolved.

\section{Summary}

Whereas closure of the Central American Seaway at about 2.8 Ma set the stage for major episodes of trans-isthmian land mammal exchanges, the well-known intervals of prior dispersals are compatible with the dynamic tectonic activity that affected the region from at least 9 Ma. Apparently those dispersals took place under generally tropical conditions in Central America, but the climate potentially was modified somewhat just before and after the Pliocene Climatic Optimum (3.25-3.05 Ma) and perhaps at about 6.0 Ma, as well, when nominally savanna-adapted taxa dispersed southward (3.7 Ma, Tayassuidae; 3.3 Ma, Camelidae).

The first significant episode of faunal exchange is recognized as GABI $1(2.6-2.4 \mathrm{Ma})$ concurrent with the initiation of major Northern Hemisphere glaciation. Then, as well as earlier and later, most northward-moving taxa were xenarthrans, with hydrochoerid and porcupine rodents being another conspicuous contingent. Eventually (GABI 2) 
more taxa dispersed southward than the reverse, but up to about $1.8 \mathrm{Ma}$, the average count for either direction was about equal. In all cases the southward contingent was phyletically more diverse and tended to include taxa of clear savanna-like ecologies. On the other hand, the northward dispersants typically included forms that exhibited a wide range of ecological diversity (xenarthrans, porcupines, and, in GABI 3 , opossums). GABI 3 represents a relatively minor episode, but is so identified on the basis of involving at least four genera in a bi-polar pattern. GABI 4, at nearly the end of the Pleistocene, shows a singularly one-way, and quite diverse, southward dispersal.

It seems that the four GABI episodes correspond at least generally to times of sea level lowering and it is tempting to suggest that expanded coastal regions contributed to dispersal in addition to a role played by climatic cooling during glacial episodes with concomitant floral changes in Central and northern South America.

Acknowledgments The author is pleased to acknowledge the efforts of L. Barry Albright, David Gillette, Gregg Gunnell, Carlos Jaramillo, Greg McDonald, and Gary Morgan who offered invaluable comments on earlier drafts of this manuscript, as did Albright and two other reviewers on the submitted version. South American colleagues Alberto E. Cione and Francisco Goin made valuable input as to the chronology and content of faunas from that region. The counsel of Alan Graham and Dolores Piperno regarding Central American floras provided a singularly significant perspective. All of these individuals are cheerfully indemnified from any implication that they necessarily agree with the conclusions presented herein. The leading role demonstrated by S.D. Webb in elucidating our understanding of the patterns and processes associated with the Great American Biotic Interchange is strongly recognized.

Open Access This article is distributed under the terms of the Creative Commons Attribution Noncommercial License which permits any noncommercial use, distribution, and reproduction in any medium, provided the original author(s) and source are credited.

\section{References}

Akers WH (1979) Planktic foraminifera and calcareous nanoplankton biostratigraphy of the Neogene of Mexico. Part 1-middle Pliocene. Tulane Studies Geol Paleont 15:1-32

Albright LB (1999) Biostratigraphy and vertebrate paleontology of the San Timoteo Badlands, Southern California. Univ Calif Publ Geol Sci:1-144

Andreissen PAM, Helmens KF, Hooghiemstra H, Riezelbos PA, Van der Hammen T (1993) Absolute chronology of the PlioceneQuaternary sediment sequence of the Bogota area, Colombia. Quaternary Sci Rev 12:483-501

Bartoli G, Sarnthein M, Weinelt M, Erlenkeuser H, Garbe-Schönberg D, Lea DW (2005) Final closure of Panama and the onset of northern hemisphere glaciation. Earth Planet Sci Let 237:33-44

Baskin JA (1982) Tertiary Procyonidae (Mammalia: Carnivora) of North America. J Vertebr Paleontol 2(1):71-93

Baskin JA (1998) Procyonidae. In: Janis CM, Scott KM, Jacobs LL (eds) Evolution of Tertiary Mammals of North America, vol 1. Cambridge University Press, Cambridge, pp 144-151
Bell CJ, Lundelius EL Jr, Barnosky AD, Graham RW, Lindsay EH, Ruez DR Jr, Semken HA Jr, Webb SD, Zakrezewski RJ (2004) The Blancan, Irvingtonian and Rancholabrean mammal ages. In: Woodburne MO (ed) Late Cretaceous and Cenozoic Mammals of North America. Biostratigraphy and Geochronology. Columbia University Press, New York, pp 232-314

Burnham RJ, Graham A (1999) The history of neotropical vegetation: new developments and status. Ann Mo Bot Gard 86:546-589

Bush MB, De Oliveira PE, Colinvaux PA, Miller MC, Moreno JE (2004) Amazonian paleoecological histories: one hill, three watersheds. Palaeogeogr Palaeoclimatol Palaeoecol 214: 359-393

Campbell KE Jr, Frailey CD, Romero-Pittman L (2000) The late Miocene gomphothere Amahuacatherium peruvium (Proboscidea: Gomphotheriidae) from Amazonian Peru: implications for the Great American Faunal Interchange. Boletin-Instituto Geologico Minero y Metalúrgico. Serie D: Estudios Regionales 23:1-152

Campbell KE Jr, Heizler M, Frailey CD, Romero-Pittman L, Prothero DR (2001) Upper Cenozoic chronostratigraphy of the southwestern Amazon Basin. Geology 29(7):595-598

Campbell KE Jr, Prothero DR, Romero-Pittman L, Hertel F, Rivera N (2010) Amazonian magnetostratigraphy: dating the first pulse of the Great American Faunal Interchange. J So Am Earth Sci 26:619-626

Carlini AA, Zurita A, Aguilera OA (2008) North American glyptodontines (Xenarthra, Mammalia) in the upper Pleistocene of northern South America. Paläont Z 82(2):125-138

Cione AL, Azpelicueta M de las M, Bond M, Carlini AA, Casciotta JR, Cozzuol MA, de la Fuente M, Gasparini Z, Goin FJ, Noriega J, Scillato-Yané GJ, Soibelzon L, Tonni EP, Verzi D, Vucetich MG (2000) Miocene vertebrates from Entre Ríos province, eastern Argentina. In: Aceñolaza FJ, Herbst R (eds) El Neogeno de Argentina. INSUGEO, Ser Correl Geol 14:191-237

Cione AL, Tonni EP (1995) Chronostratigraphy and 'Land mammalages: The Uquían problem. J Paleontol 69:135-159

Cione A L, Tonni EP (2005) Bioestratigrafía basada en mamiferos del Cenozoico superior de la Provincia de Buenos Aires, Argentina. In: de Barrio RE, Etcheverry RO, Caballé MF, Llambías E (eds) Geologia y Recursos Minerales de la Provincia de Buenos Aires. Relatorio XVI Cong Geol Arg XI:183-200

Cione AL, Tonni EP, Bargo S, Bond M, Candela AM, Carlini AA, Deschamps CM, Dozo MT, Esteban G, Goin FJ, Montalvo CI, Nasif N, Noriega JI, Ortiz Jaureguizar E, Pascual R, Prado JL, Reguero MA, Scillato-Yané GJ, Soibelzon L, Verzi DH, Vieytes EC, Vizcaíno SF, Vucetich MA (2007) Mamiferos continentales del Mioceno tardío a la actualidad en Argentina: cincuenta años de estudios. Asoc Paleontol Arg Pub Espec 11, Ameghiniana 50th aniversario:257-278

Cisneros JC (2008) The fossil mammals of El Salvador. In: Lucas SG, Morgan GS, Spielmann, JA, Prothereo DR (eds) Neogene Mammals. Bull New Mexico Mus Nat Hist Sci 44:375-380

Coates AG, Colling LS, Aubry M-P, Berggren WA (2004) The geology of the Darien, Panama, and the Miocene-Pliocene collision of the Panama arc with northwestern South America. Geol Soc Am Bull 116(11/12):1327-1344

Cronin TM, Dowsett HJ (1991) Pliocene climates. Quaternary Sci Rev 10:1-296

Dowsett H, Thompson R, Barron J, Cronin T, Fleming F, Ishman S, Poore R, Willard D, Holtz T Jr (1994) Joint investigations of the middle Pliocene climate 1: PRISM paleoenvironmental reconstruction. Global Planet Change 8:169-195

Flynn LJ (2008) Hystricognathi and Rodentia Incertae Sedis. In: Janis CM, Gunnell GE, Uhen MD (eds) Evolution of Tertiary Mammals of North America, vol. 2. Cambridge University Press, Cambridge, pp 498-506 
Flynn JJ, Kowalis BJ, Nŭnez C, Carranza-Castaňeda , Miller WE, Swisher CCIII, Lindsay EH (2005) Geochronology of Hemphillian-Blancan aged strata, Guanajuato, Mexico, and implications for timing of the Great American Biotic Interchange. J Geol 113:287-307

Forasiepi AM, Martinelli AG, Goin FJ (2007) Revisión taxonómica de Parahyaenodon argentinus Ameghino y sus implicancias en el conocimiento de los grandes mamíferos carnivoros del Mio-Pliocene de América de Sur. Ameghiniana 44(1):143-159

Gibbaard P, Head MJ, Walker M, Alloway B, Beu AG, Coltorti M, Hall VM, Liu J, Knudsen K-L, Van Kolfschoten T, Litt T, Marks L, McManus J, Partridge TC, Plotowski JA, Pillans B, Rousseau D-D, Suc J-P, Tesakov AS, Turner C, Zazo C (2010) Formal ratification of the Quaternary System/Period and the Pleistocene Series/Epoch with a base at 2.588 Ma. J Quaternary Sci 25 (2):96-102

Graham A (1973) History of arborescent temperate element in the northern Latin America biota. In: Graham A (ed) Vegetation and Vegetational History of Northern Latin America. Elsevier Science Publishers, Amsterdam, pp 301-314

Graham A (1976) Studies in Neotropical paleobotany. II. The Miocene communities of Veracruz, Mexico. Ann Mo Bot Gard 63:787-842

Graham A (1998) Studies in Neotropical paleobotany. XI. Late Tertiary vegetation and environments of southeastern Guatemala: palynofloras from the Mio-Pliocene Padre Miguel Group and the Pliocene Herrería Formation. Am J Botany 85 (10):1409-1425

Graham A (1999) The Tertiary history of northern temperate elements in the northern Latin American biota. Am J Botany 86(1):32-38

Graham A (2010) Late Cretaceous and Cenozoic history of Latin American Vegetation and Terrestrial Environments. Missouri Botanical Garden Press, St. Louis, pp 319-354

Graham A, Dilcher DL (1998) Studies in Neotropical Paleobotany. XII. A palynoflora from the Pliocene Rio Banco Formation of Costa Rica and the Neogene vegetation of Mesoamerica. Am J Botany 85(10):1426-1438

Harrison JA (1978) Mammals of the Wolf Ranch Local Fauna, Pliocene of the San Pedro Valley, Arizona. Occas Pap Mus Nat Hist, Univ Kansas 73:1-18

Honey JG, Harrison JA, Prothero DR, Stevens MS (1998) Camelidae. In: Janis CM, Scott KM, Jacobs LL (eds) Evolution of Tertiary Mammals of North America, vol 1. Cambridge University Press, Cambridge, pp 439-462

Hulbert RC Jr, Pratt AE (1998) New Pleistocene (Rancholabrean) vertebrate faunas from coastal Georgia. J Vertebr Paleontol 18 (2):412-429

Janis CM, Baskin JA, Berta A, Flynn JJ, Gunnell GF, Hunt RM Jr, Martin LD, Munthe K (1998) Carnivorous mammals. In: Janis CM, Scott KM, Jacobs LL (eds) Evolution of Tertiary Mammals of North America, vol 1. Cambridge University Press, Cambridge, pp 73-90

Koepfli K-P, Gompper ME, Eizirik E, Ho C-C, Linden L, Maldonado JE, Wayne RK (2007) Phylogeny of the Procyonidae (Mammalia: Carnivora): molecules, morphology and the Great American Interchange. Mol Phylogen Evol 43:1076-1095

Latrubesse EM, Cozzuol M, da Silva-Caminha SAF, Rigsby CA, Absy ML, Jaramillo C (2010) The late Miocene paleogeography of the Amazon Basin and the evolution of the Amazon River system. Earth-Sci Rev 99:99-124

Latrubesse EM, da Silva SAF, Cozzuol M, Absy ML (2007) Late Miocene continental sedimentation in southwestern Amazonia and its regional significance: biotic and geological evidence. J So Am Earth Sci 23:61-80
Lawrence KT, Herbert TD, Brown CM, Raymo ME, Haywood AM (2009) High-amplitude variation in North Atlantic sea surface temperature during the early Pliocene warm period. Paleoceanography 24, PA2218, doi:10.1029/PA001669

Leyden BW (1984) Guatemalan forest synthesis after Pleistocene aridity. PNAS 81:4856-4859

Lindsay EH (2008) Cricetidae. In: Janis CM, Gunnell GE, Uhen MD (eds) Evolution of Tertiary Mammals of North America, vol 2. Cambridge University Press, Cambridge, pp 456-479

Lisecki LE, Raymo ME (2005) A Pliocene-Pleistocene stack of 57 globally distributed benthic $\delta^{18} 0$ records. Palaeoceanography 20 , PA 1003

López G, Reguero M, Lizuain A (2001) El registro más antiguo de mastodontes (Plioceno tardio) de América del Sur. Ameghiniana 38:R35-R36

Lourens L, Hilgen F, Shackleton NJ, Laskar J, Wilson D (2004) The Neogene Period. In: Gradstein F, Ogg J, Smith A (eds) A Geologic Time Scale. Cambridge University Press, Cambridge, pp 409-440

Lucas SG (2008) Pleistocene mammals from Yeroconte, Honduras. In: Lucas SG, Morgan GS, Spielmann JA, Prothereo DR (eds) Neogene Mammals. Bull New Mexico Mus Nat Hist Sci 44:403-408

Lucas SG, Garcia R, Espinoza E, Alvarado GE, de Mendoza LH, Vega E (2008) The fossil mammals of Nicaragua. In: Lucas SG, Morgan GS, Spielmann JA, Prothero DR (eds) Neogene Mammals. Bull New Mexico Mus Nat Hist Sci 44: 417-430

MacFadden BJ (2000) Middle Pleistocene climate change recorded in fossil mammal teeth from Tarija, Bolivia, and upper limit of the Ensenadan land-mammal age. Quaternary Res 54:121-131

MacFadden BJ, Labs-Hochstein J, Hulbert RC Jr, Baskin JA (2007) Revised age of the late Neogene terror bird (Titanis) in North America during the Great American Interchange. Geology 35 (2): $123-126$

Marshall LG, Butler RF, Drake RE, Curtis GH, Tedford RH (1979) Calibration of the Great American interchange. Science 204:272279

Marshall LG, Berta A, Hoffstetter R, Pascual R, Reig OA, Bombin M, Mones A. (1984) Mammals and stratigraphy: geochronology of the continental mammal-bearing Quaternary of South America. Palaeovertebr Mém Extraord:1-76

Marshall LG, Webb SD, Sepkosli JJ Jr, Raup DM (1982) Mammalian evolution and the Great American Interchange. Science 215:1351-1357

McDonald HG (2005) Paleoecology of extinct xenarthrans and the Great American Biotic Interchange. Bull Florida State Mus Nat Hist 45:313-333

McDonald HG, Naples VL (2008) Xenarthra. In: Janis CM, Gunnell GE, Uhen MD (eds) Evolution of Tertiary Mammals of North America, vol 2. Cambridge University Press, Cambridge, pp $147-160$

Morgan GS (2005) The great American biotic interchange in Florida. Bull Florida Mus Nat Hist 45(4):271-311

Morgan GR (2008) Vertebrate fauna and geochronology of the Great American Biotic Interchange in North America. In: Lucas SG, Mogan GS, Spielmann JA, Prothero DR (eds). Neogene Mammals. Bull New Mexico Mus Nat Hist Sci 44:93-140

Morgan GR, Hulbert RC Jr (1995) Overview of the geology and vertebrate paleontology of the Leisey Shell Pit Local Fauna, Hillsborough County, Florida. Bull Florida Mus Nat Hist 37 (1): $1-92$

Mudelsee M, Raymo ME (2005) Slow dynamics of the Northern Hemisphere glaciation. Paleoceanography 20:PA4022. 14 p. doi:10.1029/2005PA001153 
Piperno DR (2006) Quaternary environmental history and agricultural impact on vegetation in Central America. Ann Mo Bot Gard 93:274-296

Pomi LH, Prevosti FJ (2005) Sobre el status sistemático de Felis longifrons Burmeister, 1866 (Carnivora: Felidae). Ameghiniana 42:489-494

Prevosti FJ (2006) New material of Pleistocene cats (Carnivora, Felidae) from southern South America, with comments on biogeography and the fossil record. Geobios 39:679-694

Prevosti FJ, Gasparini GM, Bond M (2006) On the systematic position of a specimen previously assigned to Carnivora from the Pliocene of Argentina and its implications for the Great American Biotic Interchange. Neues Jahrb Geol Paläontol Abh 242(1):133-144

Prevosti FJ, Pardiñas UJF (2009) Comment on "The oldest South American Cricetidae (Rodentia) and Mustelidae (Carnivora): late Miocene faunal turnover in central Argentina and the Great American Biotic Interchange" by D.H. Verzi and C.I. Montalvo [Palaeogeography, Palaeoclimatology, Palaeoecology 267 (2008) 284-291]. Palaeogeogr Palaeoclimatol Palaeoecol 280:543-54

Prevosti FJ, Rincón AD (2007) A new fossil canid assemblage from the late Pleistocene of northern South America: the canids of the Inciarte asphalt pit (Zula, Venezuela), fossil record and biogeography. J Paleontol 81(5):1053-1065

Prothero DR (1998) The chronological, climatic, and paleogeographic background to North American mammalian evolution. In: Janis CM, Scott KM, Jacobs LL (eds) Evolution of Tertiary Mammals of North America, vol 1. Cambridge University Press, Cambridge, pp 9-36

Reguero MA, Candela AM, Alonso RN (2007) Biochronology and biostratigraphy of the Uquia Formation (Pliocene - early Pleistocene, NW Argentina) and its significance in the Great American Biotic Interchange. J So Am Earth Sci 23:1-16

Sanders AE (2002) Additions to the Pleistocene mammal faunas of South Carolina, North Carolina, and Georgia. Trans Am Phil Soc 92:1-152

Shaw CA, McDonald HG (1987) First record of giant anteater (Xenarthra: Myrmecophagidae) in North America. Science 236:186-188

Simpson GG (1950) History of the Fauna of Latin America. Amer Scientist 38:361-389

Simpson GG (1953) Evolution and geography. An essay on historical biogeography with special reference to mammals. Condon Lectures Oregon State System Higher Education, pp 1-64

Soibelzon L, Tonni EP, Bond M (2005) The fossil record of South American short faced bears (Ursidae, Tremarctinae). J So Amer Earth Sci 20:105-113

Sosdian S, Rosenthal Y (2009) Deep-sea temperature and ice volume changes across the Pliocene-Pleistocene climate transitions. Science 325:306-310

Stehli FG, Webb SD (eds) (1985) The great American biotic interchange. Topics in geobiology. Plenum Press, New York

Tedford RH (1970) Principles and practices of mammalian geochronolgy in North America. Proc N Am Paleontol Conv Pt F:666-703

Tedford RH, Albright LB III, Barnosky A, Ferrusquia-V I, Hunt RM Jr, Storer J, Swisher CC III, Voorhies MR, Webb SD, Whistler DP (2004) Mammalian biochronology of the Arikareean through
Hemphillian interval (Late Oligocene through early Pliocene epochs), North America. In: Woodburne MO (ed) Late Cretaceous and Cenozoic Mammals of North America; Biostratigraphy and Geochronology. Columbia University Press, New York, pp 169-231

Tomida, Y (1987) Small mammal fossils and correlation of continental mammal deposits, Safford and Duncan basins, Arizona, USA. Tokyo. National Science Museum, pp 1-120

Tonni EP, Prado JL, Menegaz A, Salemme MC (1985) La unidad mamifero Lujanense. Proyección de la estratigrafía mamaliana al Cuaternario de la Región Pampeana. Ameghiana 22:255-261

Tonni, EP, Alberdi MT, Pardo L, Bargo MS, Cione AL (1992) Changes of mammalian assemblages in the pampean region (Argentina) and their relation with the Plio-Pleistocene boundary. Palaeogeogr Palaeoclimatol Palaeoecol 95:179-194

Verzi DH, Montalvo CI (2008) The oldest South American Cricetidae (Rodentia) and Mustilidae (Carnivora): late Miocene faunal turnover in central Argentina and the Great American Biotic Interchange. Palaeogeogr Palaeoclimatol Palaeoecol 267:284-291

Webb SD (1976) Mammalian faunal dynamics of the Great American Biotic Interchange. Paleobiology 2(3):216-234

Webb SD (1985) Late Cenozoic mammal dispersals between the Americas. In: Stehli FG, Webb SD (eds) The Great American Biotic Interchange. Plenum Press, New York, pp 357-386

Webb SD (1991) Ecogeography and the Great American Interchange. Paleobiology 17(3):266-280

Webb SD (2006) The Great American Biotic Interchange: patterns and processes. Ann Mo Bot Gard 93:245-257

Webb SD, Perrigo SC (1984) Late Cenozoic vertebrates from Honduras and El Salvador. J Vertebr Paleontol 4:237-254

Webb SD, Rancy A (1996) Late Cenozoic evolution of the Neotropical mammal fauna. In: Jackson JBC, Budd AF, Coates AG (eds) Evolution and Environment in Tropical America. University of Chicago Press, Chicago, pp 335-358

White JA (1970) Late Cenozoic porcupines (Mammalia: Erethizontidae) of North America. Am Mus Novitates 136:1-15

Woodburne MO (2004) Global Events and the North American Mammalian Biochronology. In: Woodburne MO (ed) Late Cretaceous and Cenozoic Mammals of North America: Biostratigraphy and Geochronology. Columbia University Press, New York, pp 315-344

Woodburne MO, Cione AL, Tonni EP (2006) Central American provincialism and the Great American Biotic Interchange. In: Carranza-Castañeda O, Lindsay EH (eds.) Advances in Late Tertiary Vertebrate Paleontology in Mexico and the Great American Biotic Interchange. Univ Nac Aut Mex. Inst Geol Centro Geoscien Publ Espec 4:73-101

Woodburne MO, Swisher CC III (1995) Land mammal high resolution geochronology, intercontinental overland dispersals, sea-level, climate, and vicariance. In: Berggren WA, Kent DV, Aubry M-P, Hardenbol J (eds) Geochronology, Time-scales and Global Stratigraphic Correlations: A Unified Framework for an Historical Geology. SEPM Spec Publ $54: 335-364$

Wright DL (1998) Tayassuidae. In: Janis CM, Scott KM Jacobs LL (eds) Evolution of Tertiary mammals in North America. Cambridge University Press, Cambridge, pp 389-401

Zachos J, Pagani M, Sloan L, Thomas E, Billups K (2001) Trends, rhythms, and aberrations in global climate. Science 292:686-693 